\title{
ABSTRACT \\ THE NATURAL DIVERSITY OF CARICA PAPAYA IN PANAMA
}

\author{
by Sandra Mardonovich
}

The biodiversity of wild crop species can be threatened by genetic introgression of cultivated traits from co-occurring cultivated varieties. The tropical fruit crop, papaya (Carica papaya L.), is a model organism to study questions related to crop-to-wild gene flow because it is cultivated in Central America alongside natural populations.

Morphological and genetic diversity was assessed for a collection of naturally occurring papaya individuals from four regions in Panamá, which is the southern-most extent of papaya's range. Significant morphological variation was limited, and fruit characteristics align with typical wild-type traits; fruits are small and round with a thin mesocarp and yellow flesh. Genetic analyses indicated a deficiency in heterozygosity in all regions except the Northeast region. We found moderate levels of population differentiations and regional structuring. This study provides further insight into the natural biodiversity of a tropical crop cultivated in close proximity to its wild counterparts. 


\author{
A Thesis \\ Submitted to the \\ Faculty of Miami University \\ in partial fulfillment of \\ the requirements for the degree of \\ Master of Science \\ by \\ Sandra Mardonovich \\ Miami University \\ Oxford, Ohio \\ 2016 \\ Advisor: Richard C. Moore \\ Reader: Hank Stevens \\ Reader: Michael A. Vincent
}

C2016 Sandra Mardonovich 
This Thesis titled

THE NATURAL DIVERSITY OF CARICA PAPAYA IN PANAMA

by

Sandra Mardonovich

has been approved for publication by

The College of Arts and Science

and

Department of Biology

Richard C. Moore

Hank Stevens

Michael A. Vincent 


\section{Table of Contents}

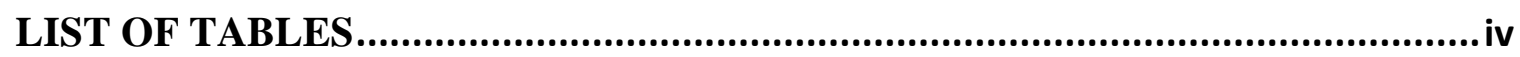

LIST OF FIGURES ..................................................................................

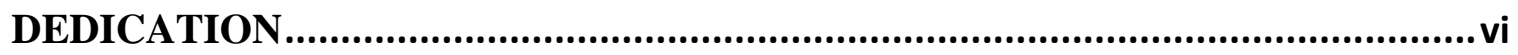

ACKNOWLEDGEMENTS ....................................................................... vii

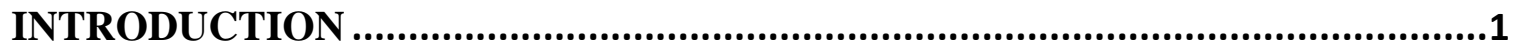

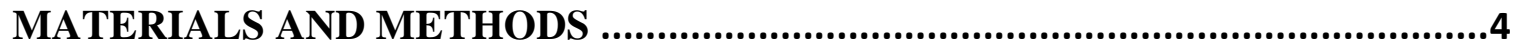

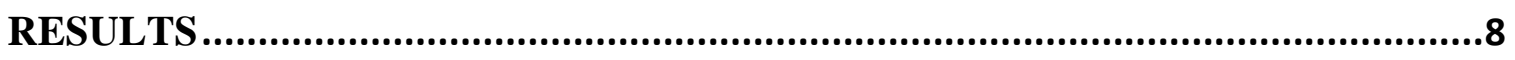

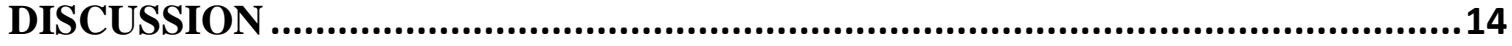

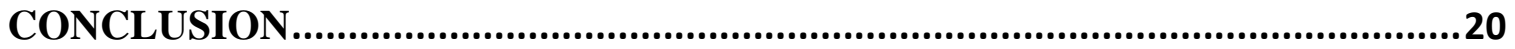

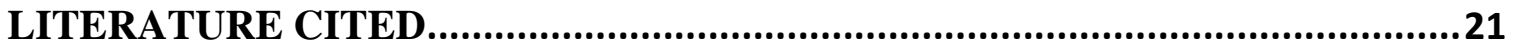

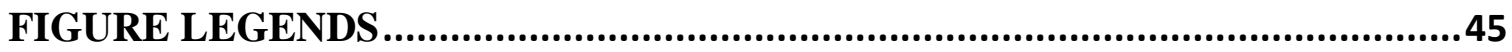




\section{LIST OF TABLES}

Table 1 - GPS coordinates of all Panama individuals and location of voucher specimen.

Table 2 - Cultivar names, accessions and place of origin.

Table 3 - Morphological characteristics adapted from International Board of Plant

Genetic Resources, 1988.

Table 4 - Microsatellite loci with primer design, size of repeat unit, linkage group, fluorophore label, marker ID and combination of primer pairs.

Table $5-\chi^{2}$ test for heterogeneity among Panamanian regions for qualitative morphological traits.

Table 6 - ANOVA results for quantitative vegetative and reproductive traits among regions.

Table 7 - ANOVA for fruit characteristics between Panamá and Costa Rica.

Table 8 - Allelic diversity and percent deviation from HWE.

Table 9 - AMOVA of wild papaya from four Panamanian regions.

Table 10 - STRUCTURE cluster percentages.

Table 11 - Panamanian regional demographics. 


\section{LIST OF FIGURES}

Figure 1 - Map of all individuals collected in Panamá.

Figure 2 - Distributions of vegetative morphological traits.

Figure 3 - Distribution of floral morphological traits.

Figure 4 - Distribution of fruit and seed characteristics.

Figure 5 - Pairwise $\mathrm{F}_{\mathrm{ST}}$ values indicating genetic differentiation between four

Panamanian regions.

Figure 6 - Principal Coordinate of Analysis.

Figure 7 - Map of Panamá with correlation to STRUCTURE clusters among the natural individuals and cultivars. 


\section{DEDICATION}

I dedicate this to the natural biodiversity of Carica papaya, may your true diversity never be lost to the evolution of the domestication of crop plants. 


\section{ACKNOWLEDGEMENTS}

There are numerous people to give thanks to for helping me throughout this project, but it'd be a long list, so THANK YOU to everyone who has helped me in some way; not just with the collections of papaya in Panamá, or the data analyses, but with the emotional support and the confidence in my ability to do this project, so many people have contributed in many different ways, and I am immensely grateful.

I want to thank my family, specifically my parents, Mirna and Nikola Mardonovich and my Grandfather Branko Martinović (Dida). To my parents, if it wasn't for how you raised me and the hardships I have seen you endure throughout your lives, I'm not sure I would have had the ability to persevere through the challenges of graduate school. "Uzdaj se use i u svoje kljuse." And to my Dida, your love for plants lives on through me, thank you for introducing me to the wonders of growing my own food. "Kopa cura vinograd!" Also, I am sincerely thankful to my major advisor, Richard C. Moore, for his scientific guidance, and for helping me turn my "Sandra-speak" into "Rich (Science)-speak" without it, this would have been a tale of my adventures in Panamá. 


\section{INTRODUCTION}

With the transition into agriculture, humans began to select specific plant traits that appealed to their needs and changed the landscape around them to accommodate farming practices (Doebley et al., 2006). As people became more knowledgeable in their selection of specific traits, they slowly modified the original version of the plant into a "better" version. In a process known as the domestication syndrome, food crops diverged from their wild progenitors morphologically and physiologically; for example, crops tend to have larger fruits, determinate growth, lack seed dormancy and have sweeter tastes (Doebley et al., 2006; Brown et al., 2009). The selection of these specific traits in crops, however, may lead to the loss of other traits, such as disease resistance, present in the wild progenitor. As a consequence, the derived crop may have reduced genetic diversity relative to its wild progenitor.

Humans have not only directly modified the molecular genetics of crops, but have also changed the landscape to accommodate modern farming practices to feed an exponentially growing population. This is particularly true in tropical regions, for example, anthropogenic disturbances have led to enhanced successional change in abandoned pastures of Costa Rica and tropical forests of Panamá (Cespedes et al., 2003; Svenning et al., 2006). The diversity of wild crop relatives may also be affected by these altered landscapes by isolating populations and altering patterns of gene flow. The effects of fragmented landscapes on genetic structure and gene flow among wild plant populations can vary and may be either advantageous or detrimental. Some studies have shown that gene flow is high for tropical plants in disturbed landscapes (Hamrick et al., 1991; Rocha \& Aguilar, 2001). For example, in Swietenia humilis, a tropical deciduous tree, spatial isolation and forest fragmentation promoted pollen flow and outcrossing between fragmented populations by facilitating long distance travel $(>4.5 \mathrm{~km})$ of its small generalist insect pollinators (White et al., 2002). Empirical data has also indicated that gene flow between remnant plant populations created by landscape fragmentation increases due to increased mobility of pollinators with extensive foraging ranges, including hawkmoths, hummingbirds, bat, and large bees (Nason \& Hamrick, 1997). For example, it was shown using allozyme markers that pollen flow rates were highest in small, isolated populations of Spondias mombin, another tropical tree, increasing rates of outcrossed progeny (Nason \& Hamrick, 1997). In contrast, habitat fragmentation can also result in small, isolated populations that are more susceptible to genetic drift and increased rates of inbreeding, either through self-pollination or 
biparental inbreeding (Ellstrand \& Elam, 1993; Young et al., 1996; Aguilar et al., 2008), and can lead to a decline in heterozygosity. These effects are accelerated in populations of short-lived dioecious species, as fragmentation may lead to small, isolated single-sexed populations, separating males and females over long distances (Young et al., 1996; Chaìvez-Pesqueira et al., 2014).

More recently there has been a focus on gene flow and the effects of crop-to-wild gene flow and how increased gene flow creates greater risk of gene introgression if wild plant species are grown near their domesticated counterparts, potentially introducing alleles that are not beneficial in the wild. For example, alleles from domesticated almond have introgressed into their wild relatives (Delplancke et al., 2012), while gene flow between cultivated sunflowers and wild progenitors has been documented up to $1000 \mathrm{~m}$ (Arias \& Rieseberg, 1994). There is also evidence for gene exchange between cultivated wheat and its wild counterparts (Arrigo et al., 2011). There have been numerous studies indicating the potential damage of crop-to-wild gene flow (Ellstrand et al.,1999; Delplancke et al., 2012), and the risk of aggressive weeds being developed (Trucco et al., 2009; Burke et al., 2002). The consequences of crop-to-wild gene flow are particularly important to study in cultivated crop species that are grown in areas native to their wild counterpart.

Carica papaya L., commonly known as papaya, is a tropical fruit crop that is native to Mesoamerica, but is also cultivated in that region as well as world-wide in tropical environments. Papaya's main economic value is its nutrient-rich fruits; these fruits are a source of antioxidant nutrients, such as vitamins C, carotenes, B vitamins, and fiber (Evans \& Ballen, 2012; Organisation for Economic Co-operation and Development [OECD], 2005). Many small-scale farmers in tropical regions worldwide in developing countries depend on papaya as their source of nutritional content and an extra source of income through sale of the fruit at markets (Martins $\&$ Johnson, 2009). For example, up to $61 \%$ of rural populations in Panamá live below the poverty threshold (Rompré et al., 2008), and impoverished people in rustic areas tend to clear land as a means to support their families because they do not have other economic opportunities (Rudel \& Roper, 1997). The papaya fruit is also highly valued because of its production of the proteolytic enzyme papain, which is used worldwide as a meat tenderizer (Carvalho \& Renner, 2012; OECD, 2005) and for chill proofing beer (Ming et al., 2012). As such an important 
tropical fruit crop, its natural biodiversity is possibly in danger due to the potential risks of landscape alteration affecting gene flow among populations and crop-to-wild introgression.

The distribution of wild papaya extends from southern México down to Costa Rica (Carvalho \& Renner, 2012; Manshardt \& Zee, 1994) and even Panamá (Nakasone \& Paull, 2008). Several studies have sought to characterize the genetic and/or morphological diversity of wild papaya as well as the potential of gene flow between wild and domesticated papaya. Manshardt and Zee (1994) conducted a field study on wild papaya from Central America and characterized wild papaya as exclusively dioecious with small, yellow to orange fleshed, golfball sized fruits densely packed with seeds. These observations were further supported by d'Eeckenbrugge et al. (2007) when they observed similar fruit traits on the Pacific side of Costa Rica. In a study of wild papaya populations in the Los Tuxtlas regions of southern México, it was shown that gene flow was impeded between populations growing in fragmented forests versus those grown in continuous forests. Furthermore, populations in fragmented forests had lower genetic diversity and higher population differentiation than those in continuous forests (Chaìvez-Pesqueira et al., 2014). Brown et al., (2012) conducted a survey of genetic and morphological variation for over 250 individuals from five regional populations across Costa Rica and found high levels of genetic diversity, with low to moderate population differentiation and increased inbreeding possibly due to habitat fragmentation. These genetic diversity results were higher than an isozyme analysis of wild individuals in Costa Rica (d'Eeckenbrugge et al., 2007). These studies have provided insight into the population genetics of an important tropical crop that may be in danger of loosing its natural genetic diversity.

In this study, we assessed the distribution of morphological and genetic variation among natural papaya populations in Panamá. Panamá represents the most southern extent of wild papaya's range in Central America and is most distant from the hypothesized center of origin for papaya in Southern México (Manshardt \& Zee, 1994). We asked a number of questions: 1) What is the degree of morphological variation in naturally occurring papaya in Panamá? 2) What is the level and structure of genetic diversity and gene flow in these natural papaya populations? 3) Is there evidence of crop-to-wild gene flow from cultivated papaya into its wild counterparts? In order to address these questions we characterized morphological traits of wild papaya set forth by the International Board of Plant Genetic Resources (IBPGR, 1988) and compared fruit characteristics to previous observations in Costa Rica (Brown et al., 2012). We also assessed 
genetic diversity, population structure and demography using 20 microsatellite markers. We found limited morphological variation among Panamanian papaya, and most exhibited the phenotypic traits typically associated with wild papaya, including small, yellow-fleshed, seedy fruits. Levels of genetic diversity of natural papaya populations in Panamá are comparable to that found in southern México and Costa Rica, with moderate levels of inbreeding detected. The Western region of Panamá was most highly differentiated from the other regions assessed, while the Canal was a "hot-spot" for admixture among wild papaya genotypes. We found evidence of low levels of introgression of cultivated papaya into wild papaya populations, though the greatest incidence of cultivated genotypes was found in the Canal and Southern regions.

\section{MATERIALS AND METHODS}

Plant material and study site-Young leaf tissue was collected during the wet season in Panamá during the months of May-June in 2013 from 82 papaya individuals (32 females, 26 males, 24 juvenile/sterile) growing naturally along the Interamericana Highway and other Panamanian roadways. Due to the sparse distribution of individuals in the landscape, we divided them into four larger regional populations: 1) the Western region, consisting of the western-most part of the country in the Provinces of Bocas del Toro and Chiriquí; 2) the Southern region, including the Provinces of Veraguas, Coclé and Panamá; 3) the Northeast region in the Province of Colón; and 4) the Canal region, collected along the Panamá Canal in the Panamá province (Fig. 1). Global positioning system (GPS) coordinates were recorded for each individual and herbarium vouchers were made for each regional population ( 9 vouchers in Northeast, 29 in Canal, 7 from the South, 6 in the West; Table 1). Herbarium vouchers are housed at the Willard Sherman Turrell Herbarium at Miami University and the Smithsonian Tropical Research Institute Herbarium in Panamá (Table 1). Leaf tissue was dried in silica gel and stored in $-80^{\circ} \mathrm{C}$ freezer prior to DNA extraction. Leaf tissue for 14 cultivars (four unimproved breeding lines and ten unimproved germplasm [Kim et al., 2002]) were donated by Ray Ming of the University of Illinois and Qingyi Yu from Texas A \& M (Table 2).

Morphological data collection-Quantitative and qualitative data of vegetative and reproductive characteristics were measured for individual plants in situ. Fifteen morphological traits were assessed based off of descriptors set forth by IBPGR (1988) for C. papaya. Quantitative traits 
included diameter of fruit, leaf width and length, and length of petiole (Table 3). Qualitative traits included, inflorescence stalk color, leaf petiole color, leaf shape, leaf teeth shape, shape of petiole sinus, fruit skin color, flower color of females, shape of fruit central cavity, shape of fruit stalk end, seed color, seed surface luster, and color of the male flower- corolla lobe and corolla tube (Table 3).

The most mature leaves positioned at the first vegetative node basal to the crown were used for quantitative measurements of leaf morphology. The length of the entire petiole was measured. Leaf length was measured from the point of petiole attachment to the tip of the center lobe. The leaf width was measured at the broadest point on the leaf, from the tip of one lobe to the tip of the opposite lobe. Fruit diameter was evaluated by measuring the widest point of a fruit cross-section cut at its maximum diameter.

Morphological data analysis - Qualitative and quantitative morphological traits were analyzed with the statistical program JMP 11 (SAS Institute Inc., 2009, 2013). Heterogeneity in qualitative morphological traits among Panamanian regions was tested using a contingency analysis, which tests the null hypothesis that phenotypes are independent of region. Significance of the contingency analysis was assessed by the likelihood ratio and Pearson $\chi^{2}$ tests. The means of quantitative traits were compared among Panamanian regions using Analysis of $\underline{\text { Variance }}$ (ANOVA). An ANOVA was also used to compare means of fruit diameter between Panamá and Costa Rica. For this analysis, fruit diameter data for three Panamanian regions (Canal, South, West) were combined due to the low number of fruiting females in any one region; the Northeastern region in Panamá had no fruiting females and was not included in this comparison. The mean fruit diameter for this combined Panamanian region was then compared to the means of the five Costa Rican regional populations identified in Brown et al. (2012).

Microsatellite data - Genomic DNA was extracted from silica-dried leaves with QIAGEN DNeasy Plant Mini-Kits (QIAGEN, Germantown, Maryland) and diluted to 40ng/ $\mu$ L. Twenty microsatellite markers designed by Chen et al. (2007) and used previously by Brown et al. (2012) for Costa Rican papaya populations were used to quantify levels of genetic diversity in natural papaya and cultivars (Table 4). The 20 microsatellite loci selected for the study are distributed across the nine major linkage groups of papaya and lack segregation distortion (Chen 
et al., 2007; Brown et al., 2012). Co-dominant molecular markers were used because of their effectiveness in identifying two alleles at a given gene in diploid organisms and their usefulness in exploring processes such as gene flow and dispersal related to their interactions with evolutionary processes and landscapes (Holderegger et al., 2006).

Polymerase Chain Reaction (PCR) was used to amplify microsatellite markers at a total volume of $20 \mu \mathrm{L}$ containing: $1 \mu \mathrm{L}$ of $40 \mathrm{ng} / \mu \mathrm{l}$ DNA template, $10 \mu \mathrm{L}$ of $5 x$ Colorless GoTaq Master Mix (Promega, Madison, WI), $1.25 \mu \mathrm{L}$ of $10 \mu \mathrm{M}$ fluorescently labeled forward primer (Applied Biosystems Inc., Foster City, CA), and $1.25 \mu \mathrm{L}$ of $10 \mu \mathrm{M}$ of non-labeled reverse primer (Integrated DNA Technologies Inc., Coralville, IA). The reaction was run at $94^{\circ} \mathrm{C}$ for $2 \mathrm{~min}$, followed by 35 cycles of $94^{\circ} \mathrm{C}$ for $30 \mathrm{sec}, 56^{\circ} \mathrm{C}$ for $30 \mathrm{sec}, 72^{\circ} \mathrm{C}$ for $1 \mathrm{~min} 30 \mathrm{sec}$, and then a final extension period at $72^{\circ} \mathrm{C}$ for $5 \mathrm{~min}$, using a BIO-RAD Peltier Thermal Cycler TC-0200 (MJ Research, Inc., Waltham, MA). PCR amplification was confirmed using a 2\% agarose gel stained with ethidium bromide prior to pooling multiple PCR samples into one tube.

A pseudo-multiplexing strategy was used to pool differentially labeled marker sets into one volume to be separated using capillary electrophoresis on an ABI 3730 DNA Analyzer (Applied Biosystems Inc., Foster City, CA) at the Center of Bioinformatics and Functional Genomics (CBFG) at Miami University. Dye-labeled forward primers were designed based on the Applied Biosystems Dye Set G5 (6FAM, HEX, NED, PET). PCR products from two separate microsatellite amplifications (each diluted 1:50) were pooled together for a 1:1 master mix and then further diluted to 1:60, giving a final dilution of 1:3000 (see Table 4 for pooled primer reactions). To prepare PCR samples for separation, $1.5 \mu \mathrm{L}$ of the pooled and diluted PCR product was combined with $12 \mu \mathrm{L}$ Hi-Di Formamide (Applied Biosystems Inc., Foster City, CA) and 0.12 $\mu$ L GeneScan 600 LIZ Size Standard v2.0 (Applied Biosystems Inc., Foster City, CA). The mixture was heated in a thermocycler at $94^{\circ} \mathrm{C}$ for ten min and $4{ }^{\circ} \mathrm{C}$ for 2 min and then submitted to CBFG. Allele sizes were determined using Peak Scanner Software version 1.0 (Applied Biosystems Inc., Foster City, CA). Data compiled from Peak Scanner was exported to FlexiBin, which is an Excel Macro program where fragments were classified into alleles categories according to their lengths and graphs are output to visualize the distribution of alleles and outliers (Amos et al., 2007). 
Genetic analyses-Allele fragments were binned to their respective allele classes, and then exported into Genetic Analysis in Excel (GenAlEx) 6.5 (Peakall \& Smouse, 2006, 2012) and Arlequin 3.5 (Excoffier et al., 2005, Excoffier \& Lischer, 2010) in order to analyze genetic variation within and between the regional populations. Genetic diversity was assessed by calculating the number of alleles per locus $(A)$, expected heterozygosity $\left(H_{E}\right)$, and observed heterozygosity $\left(H_{O}\right)$ in Arlequin 3.5. The exact test by Guo \& Thompson (1992) was performed to determine any deviations from Hardy-Weinberg equilibrium (HWE). The fixation index for the four Panamanian regions was calculated by the equation: $F=\left(H_{E^{-}} H_{O}\right) / H_{E}$ to quantify deficiencies in observed heterozygosity relative to expected heterozygosity.

The structure of genetic diversity was assessed with Arlequin 3.5 using Analysis of Molecular Variance (AMOVA) (Excoffier et al., 2005, Excoffier \& Lischer, 2010). F-statistics ( $\mathrm{F}_{\mathrm{ST}}, \mathrm{F}_{\mathrm{IS}}, \mathrm{F}_{\mathrm{IT}}$ ) were calculated to determine the correlation of alleles at different population levels (Excoffier et al., 1992). The $\mathrm{F}_{\mathrm{ST}}$ statistic evaluates population differentiation among the subdivisions, $F_{\text {IS }}$ is the local inbreeding coefficient within individuals of the subdivisions, and $\mathrm{F}_{\text {IT }}$ is the fixation index for the subdivisions over the total population (Wright, 1965). A pairwise $\mathrm{F}_{\mathrm{ST}}$ matrix was calculated to determine the level of variation among natural regions and cultivars (Excoffier et al., 2005, Excoffier \& Lischer, 2010) to identify the relatedness between regions. A Principal Coordinate of Analysis (PCoA) was performed in GenAlEx 6.5 in order to visualize genetic distance among individuals (Peakall \& Smouse, 2006, 2012).

Population structure was further analyzed with STRUCTURE 2.3.4, which performs Bayesian based clustering analysis and assigns each sample into a Cluster $(K)$ (Falush et al., 2007). STRUCTURE analysis identifies cryptic population structure and admixture, if any (Falush et al., 2007). STRUCTURE runs used a burn-in length of 20,000, and 100,000 repetitions after burn-in. STRUCTURE HARVESTER was used to process STRUCTURE results to determine the average possibilities of values per $K$ with the Evanno et al. (2005) method (Earl \& vonHoldt, 2012). To create STRUCTURE graphics, DISTRUCT was utilized to assign each individual with a color that corresponds to its subdivision, $K$ (Rosenberg, 2004).

Population demography analyses-The Garza-Williamson index, $M$, was used to detect the signature of a recent reduction in population size. $M$ is calculated with microsatellite loci based on the average mean of the amount of alleles to the range of allele size (Garza \& Williamson, 
2001). Population expansion was assessed in an Excel Macro program developed by Bilgin (2007) that implements against a null hypothesis with two different tests; the within locus $k$ test and the interlocus $g$ test (Reich \& Goldstein 1998, Reich et al., 1999). The imbalance index, $\beta$, is a statistical analysis for microsatellite data to infer past population expansion that compares two estimators of $\theta$, which are estimates of allele size and homozygosity (Kimmel et al., 1998; King et al., 2000). The parametric value of $\beta>1$ is consistent with population growth followed by a bottleneck (Kimmel et al., 1998).

\section{RESULTS}

\section{Variation in vegetative morphology among Panamanian regional populations - Many}

leaf morphological traits exhibited similar ranges of phenotypic variation among the four Panamanian regions (Table 5,6). Convex leaf teeth were almost exclusively observed across all regions, with a minority (less than $8 \%$ ) of leaves in the Canal and Northeastern regions exhibiting straight leaf teeth (Fig. 2B). The petiole sinus predominantly ranged from slightly closed to closed (41\% to $43 \%$ of all regions), though a minority of leaves exhibited slightly open sinuses (14\% of all regions); only one leaf had an open sinus in the Canal region (Fig. 2C). Mean leaf length and width were also similar among regions (ANOVA, $P>0.05$ ); mean leaf length ranged from $38.8 \pm 3.9 \mathrm{~cm}$ in the Southern region to $51.0 \pm 3.8 \mathrm{~cm}$ in the Western region, while mean leaf width ranged from $58.1 \pm 6.6 \mathrm{~cm}$ in the Southern region to $77.0 \pm 6.3 \mathrm{~cm}$ in the Western region (Table 6).

Variable morphological traits included leaf petiole color $(P<0.04$ [log-likelihood only]), leaf shape $(P<0.02)$ and mean petiole length (ANOVA, $P<0.03$; Table 5$)$. 'Pale-green' to 'normal-green' petioles were most frequently observed in the Canal, Northeastern, and the Southern regions (74\% of all regions; Fig. 2A). Red-purple petioles were infrequently observed in most regions (10\% of all individuals) and were absent in the Southern region. Green petioles with shades of red-purple were observed only in the Southern (29\%) and Western (29\%) regions. Mean petiole length was significantly shorter in the Southern region $(61.3 \pm 7.9 \mathrm{~cm})$ compared to the other regions (ranging from $79.7 \pm 7.9 \mathrm{~cm}$ in the Northeast to $97.3 \pm 7.5 \mathrm{~cm}$ in the West; Table 6).

Variations in leaf shape were more complex, as the IBPGR descriptors recognize 16 leaf shape phenotypes (IBPGR, 1988). The Canal region exhibited the most variation in leaf 
shape, exhibiting nine different leaf shape phenotypes. Most frequently observed were phenotypes 1 (21\%), 3 and 4 (both, 17\%), and 7 (14\%; Fig. 2D). Leaf shapes 1 and 3 both have broad, primary lobes with few broad, secondary lobes. Leaf shape 4 is more deeply lobed with more secondary lobes (Fig. 2D). The most frequent leaf shapes for the Northeastern region were phenotypes $6(50 \%)$ and $12(38 \%)$. Leaf shape 6 has narrow primary lobes and highly dissected secondary lobes, while leaf shape 12 also has narrow primary lobes but lacks dissected secondary lobes. The most frequent leaf shape for the Southern region was leaf shape 2 (38\%). Leaf shape 2 was only observed in the Southern region and is differentiated by the asymmetric distribution of secondary lobes. Leaf shape 14 was also only observed in the Southern region, and is distinguished by particularly thin primary lobes and a lack of deeply dissected secondary lobes. The Western region was dominated by phenotype 1 (40.0\%) as described above (Fig. 2D).

\section{Variation in reproductive morphology among Panamanian regional populations -All}

populations were dioecious, with solitary flowers found on females and long inflorescences found on male plants (Table 5). The inflorescence stalk was mostly 'greenish' and did not vary significantly among the four regions (Table 5). Female flowers were almost exclusively whiteyellow (cream) in all regions, with one individual possessing 'yellow/green with shades of redpurple' flowers in the Canal region (Fig. 3D). White-yellow (cream) colored male flowers were observed in the Canal, Southern, and Northeastern regions, while white flowers were also observed in the Canal region (Fig. 3A, B).

Most fruit and seed traits did not vary significantly among regions, including fruit shape, fruit skin color, flesh aroma, shape of fruit stalk end, seed surface luster, and seed shape (Table 5). The statistical power of these comparisons was limited, however, as only nine mature and two immature fruit were found within the Canal, Western, and Southern regions. Fruits were predominantly round in all three regions, though the Canal region was the most variable, with round, oval, and acorn shapes (Fig. 4A). In addition, turbinate inferior- and acorn-shaped fruit were also observed in the Western region. Fruit skin ranged from green (unripe) to light yellow or deep yellow and orange (Fig. 4B). Most fruits in the Canal region and Western regions were flattened at the fruit stalk end (both, 30\%), though a depressed end was observed at minor frequencies in both regions and in the Southern region (Fig. 4E). Seed surface luster was scored in nine individuals from the Canal and Western regions, and 'generally dull' was most frequently 
observed throughout (data not shown). Seeds were uniformly spherical or ovoid shaped (Fig. $4 \mathrm{~F})$.

Significant variation was observed for fruit flesh color $(P<0.05)$, the shape of the central cavity $(P<0.05)$ and seed color $\left(P<0.02\right.$ [Pearson $\chi^{2}$ only]; Table 5$)$. Fruit flesh color was almost exclusively deep yellow to orange, with the notable exception of a light yellow-fleshed individual in the Southern region; no red fleshed fruits were observed (Fig. 4C). The central cavity was intact and shape of the central cavity could only be assessed in the Canal and Western regions. Fruits in the Canal region had slightly star-shaped or star-shaped central cavities; in contrast, fruits in the Western region were exclusively round (Fig. 4D). The Canal and the Western regions both exhibited 'generally black' seed color. On the contrary, the one fruit from the Southern region had one sample for seed color and it was scored as 'generally grey' (Fig. $4 \mathrm{~F})$.

Previous reports have described a gradient of small-fruited papaya gradually increasing in size from Southern México to Panamá (Manshardt \& Zee, 1994), as well as from north to south within Costa Rica (Brown et al., 2012). In contrast, fruit diameter did not vary significantly among Panamanian papaya populations. Mostly small fruit were found in the Western and Canal regions (means $3.9 \pm 0.2 \mathrm{~cm}$ and $5.9 \pm 0.6 \mathrm{~cm}$ ), however one larger fruited papaya was found in the Southern region $(8.1 \mathrm{~cm}$ in diameter). The mean fruit diameter for all Panamanian papaya was also compared to the mean diameters for Costa Rican populations (Table 7; Costa Rican data from Brown et al., 2012). The mean size of Panamanian papaya $(5.7 \pm 0.6 \mathrm{~cm})$ was significantly smaller (ANOVA, $P<0.09$ ) than the papaya in the Southwest Pacific region of Costa Rica $(9.0 \pm 0.8 \mathrm{~cm})$ and was smaller, though not significantly, than all other Costa Rican regions (means range 6.6 to $7.6 \mathrm{~cm}$ ) except those in the Nicoya region $(5.2 \pm 0.2 \mathrm{~cm})$.

Levels and patterns of genetic diversity within Panamanian regional populations - The genetic diversity of 82 papaya from four regional Panamanian populations as well as a sample of four unimproved and ten improved cultivars (Table 1,2) was assessed based on the average number of observed alleles per locus $(A)$, expected heterozygosity $\left(H_{E}\right)$, and observed heterozygosity $\left(H_{O}\right)$ for 20 microsatellite loci (Table 7). Moderate allelic diversity was observed in the regions, with $A$ ranging from 3.8 to 6.7. As well, the average $H_{E}$ for regional populations ranged from 0.56 to 0.66 . Moderate levels of diversity were also observed in cultivars $\left(A=5.2, H_{E}=0.68\right.$; 
Table 8). Observed heterozygosity, however, was reduced relative to $H_{E}$ in the Canal, Western and Southern regions, ranging from 0.46 to 0.53 . For these populations, the fixation index, $F$, which measures the deficiency of heterozygotes in the population, ranged from 0.17 to 0.20 . This deficiency deviated significantly from Hardy Weinberg Expectation (HWE) for 0 to $35 \%$ of the loci in the Canal, Western and Southern regions (Bonferroni corrected $P<0.05$; Table 8); with the Canal region deviating the highest from HWE (35\%). In contrast, mean $H_{O}$ for the Northeastern region $\left(H_{O}=0.70\right)$ was greater than mean $H_{E}$, characterized by a negative fixation index $(F=-0.26)$; however, this difference deviated significantly from HWE for only a minority $(10 \%)$ of loci in this population (Table 8$)$. The cultivars had the highest deficiency in heterozygotes $(H o=0.24$ and $F=0.64)$, with $65 \%$ of the loci deviating significantly from $\mathrm{HWE}$ (Table 8).

The structure of genetic diversity among regional populations - Based on an AMOVA, genetic variation was predominantly found within individuals (79.9\%), while $13.5 \%$ of the variation was found among individuals within populations, and $6.6 \%$ of the variation was partitioned among populations. $\mathrm{F}_{\mathrm{IS}}$, the inbreeding coefficient, was consistent with moderate levels of inbreeding within populations $\left(\mathrm{F}_{\mathrm{IS}}=0.14\right.$; Table 9$)$. Differentiation among regions, $\mathrm{F}_{\mathrm{ST}}$, was moderate overall $\left(\mathrm{F}_{\mathrm{ST}}=0.066\right)$; however, pairwise $\mathrm{F}_{\mathrm{ST}}$ between regional populations ranged from 0.035 to 0.21 (Fig. 5). The Western region had the highest differentiation among the three natural regions, with pairwise $\mathrm{F}_{\mathrm{ST}}$ values ranging from 0.095 (compared to the South) to 0.21 (compared to the Northeast), while the more centrally located Canal region was the least differentiated among the three natural regions $\left(0.035<\mathrm{F}_{\mathrm{ST}}<0.10\right.$; Fig. 5). Natural populations were moderately to highly differentiated from cultivars, with $\mathrm{F}_{\mathrm{ST}}$ ranging from 0.07 to 0.19 (Table 10). The Southern region exhibited the least differentiation with the cultivars $\left(\mathrm{F}_{\mathrm{ST}}=0.07\right)$, while the Western region was most highly differentiated $\left(\mathrm{F}_{\mathrm{ST}}=0.19\right.$; Fig. 5).

These patterns of differentiation are reflected in a PCoA, which assesses genetic relationships of individuals within the regions; coordinate 1 contains $13.1 \%$ of the variation and coordinate 2 contains $7.6 \%$ of the variation (Fig. 6). The Western and Northeastern individuals were genetically distinct; whereas individuals from the Canal and Southern regions were scattered across all quadrants consistent with a lack of genetic differentiation between these regions (Fig. 6). The cultivars had a wide distribution with majority of the individuals in 
quadrant I, and only one individual in quadrant II and another in quadrant IV. Interestingly, Pa42 from the Canal region and the SunUp cultivar (improved from Hawaii) are completely overlapped in quadrant I, which supports their STRUCTURE clustering with $100 \%$ shared ancestry.

Four significant clusters of shared genetic ancestry $(K=4)$ were identified in the natural and cultivar populations using STRUCTURE (Pritchard et al., 2000) and STRUCTURE HARVESTER (Earl \& vonHoldt, 2012). Individuals in the Western region belonged almost exclusively to Cluster 2, with nine of the ten individuals sharing at least $92 \%$ ancestry with Cluster 2 (light blue, Fig. 7; Table 10), with the exception of one individual, Pa5, which was assigned $78 \%$ shared ancestry with Cluster 3 (green) and only 19\% with Cluster 2 (Table 10). Most individuals in the Southern region likewise belonged to Cluster 2, except for two individuals that were assigned to Cluster 4 (yellow), which included the improved cultivars. Pa11 had 97\% shared ancestry with Cluster 4; and Pa14 had admixture with Cluster 4 (67\%) and Cluster 2 (23\%; Fig. 7; Table 10). Individuals in the Northeastern region, in contrast, were primarily derived from Cluster 3 (seven of ten individuals) with minimum 98\% shared ancestry, but three of the individuals were assigned to Cluster 2 with at least 95\% shared ancestry (Table $10)$.

The Canal region exhibited the most genetically diverse representation of genetic ancestry. First, individuals assigned to Cluster 1 (purple) are exclusively found in the Canal region, with eight individuals belonging to this cluster (at least 87\% shared ancestry; Fig. 7; Table 10). Second, individuals from Cluster 2 (24 individuals) and Cluster 3 (14 individuals) were almost equally represented, with a number of individuals exhibiting signs of admixture between these two clusters with less than $90 \%$ identity belonging to either cluster (Fig. 7, Table 10). Finally, one individual from the Canal region, Pa42, identified $100 \%$ with the cultivar Cluster 4 (Fig. 7, Table 10).

Within the cultivars, eight out of fourteen were assigned to Cluster 4 (with at least $89 \%$ shared ancestry), and six of these eight were improved cultivars from various places from the globe (Hawaii, Taiwan, and Colombia via Florida). The improved cultivar, DREW from Australia, shared 95\% ancestry with Cluster 2.Three of the improved cultivars (CO_H, No. 31, Kaek Dum) had shared ancestry between Clusters 2 and 4. Interestingly, CO_H from India mostly belonged to Cluster 2 (74\%); while No. 31 and Kaek Dum (from Cuba and Thailand) 
mostly shared ancestry with Cluster 4 (63\% and 71\%). Only two of the unimproved cultivars (H16_F from Malaysia, 918H from Costa Rica) identified mostly closely with Cluster 4, with 98\% shared ancestry. An unimproved cultivar from Costa Rica (928M) had 81\% shared ancestry with Cluster 2, the predominant cluster found in the Western region of Panamá. One unimproved cultivar from Panamá, HCAR14, had shared ancestry with Clusters 3 and 4, although majority of its genotype (77\%) was assigned to Cluster 3. Interestingly, $70 \%$ of individuals in the Northeastern region, and $77 \%$ of the individuals in the Canal region were assigned to Cluster 3 (Fig. 7; Table 10).

The demographic history of Panamanian papaya populations - Previous analyses of natural papaya from Costa Rica suggested that those populations had undergone a bottleneck followed by an increase in population in size (Brown et al., 2012). Several analyses were performed to determine if the natural populations in Panamá have a similar demographic history due to the extensive land transformation throughout the Canal region during the development of the Canal and deforestation in rural areas to create pasturelands (Condit et al., 2001). The GarzaWilliamson index, $M$, can deduce if a population has recently undergone a reduction in size by comparing the average proportion of the number alleles to the range in allele size. The Panamanian regional populations had an $M=0.599$, which is below the critical value of 0.70 , consistent with a reduction in population size. The $M$ value ranged from 0.527 to 0.685 for the regional populations, and the cultivars had an $M$ value of 0.549 (Table 11).

The signature of population expansion was first assessed by using the $k$ and $g$ tests (Reich et al., 1999). The within-locus $k$ statistic is a measure of the peakedness of the allele frequency distribution, which is unimodal and more peaked following an expansion (Reich et al., 1999; Reich \& Goldstein, 1998). The $k$ statistic was not significant for all the natural regions and the cultivars ( $P$-values ranged from 0.36 to 0.99 ; Table 11$)$; in contrast, the Western region had a significant $k$ statistic $(P=0.04$, Table 11$)$, which supports population expansion. The interlocus $g$ statistic tests the variance in the widths of allele length frequencies across loci to determine if there has been an increase in population size; typically $g<1$ indicates expansion (Reich et al., 1999; Reich \& Goldstein, 1998; King et al., 2000). The inter-locus $g$ variable for natural papaya regions ranged from 4.06 to 7.82 and was 1.76 for cultivars, inconsistent with the signature of a population expansion (Table 11). 
The $k$ and $g$ tests are less effective at detecting very recent population expansions, whereas the imbalance index $\beta$ is more sensitive to recent expansions and has the capability of detecting an increase in size following a bottleneck (King et al., 2000). The imbalance index $\beta$ was computed as $\ln \beta_{1}$ and $\ln \beta_{2}$ in all four natural regions in Panamá and ranged from 0.5922.215 and $0.463-1.178$, respectively (Table 11). All values fall outside the $99 \%$ confidence interval of $\ln \beta$ for a population of constant size and are consistent with a population that experiences a bottleneck followed by an increase in population size (Kimmel et al., 1998). Such a population is characterized initially by $\beta>1($ or $\ln \beta>0)$, after which $\beta$ falls below $1(\ln \beta<0)$. The $\ln \beta$ for all four regions together $\left(\ln \beta_{1}=1.547\right.$ and $\left.\ln \beta_{2}=1.071\right)$ as well as for cultivars $\left(\ln \beta_{1}\right.$ $=1.509$ and $\ln \beta_{2}=1.291$ ) also supported this demographic model.

\section{DISCUSSION}

\section{Limited morphological variation exists in natural papaya from Panamá —Significant}

phenotypic variation among the four Panamanian regions was observed in only a few traits, including leaf petiole color, leaf shape, fruit central cavity shape and seed color. The significant variation seen in leaf petiole color could be due to the difference in the production of anthocyanins (Konczak \& Zhang, 2004; Deroles, 2009), which play a major role in photoprotection (Deroles, 2009) and could be responsible for the light green to red-purple hues observed on the papaya leaf petioles. This difference in anthocyanin production may be genetically determined or be a result of morphology plasticity (Manshardt \& Zee, 1994; Ellstrand et al., 1999) that is brought on by different environmental conditions such as intense direct lighting or water exposure (Klich, 2000). Significant leaf shape variation could be attributed to varying habitat conditions relating to the wet and dry seasons of Panamá. Deep lobing in angiosperm leaves has been shown to aid in thermoregulation and have a positive aspect on hydraulic efficiency (Nicotra et al., 2011) and may be important for papaya due to its exposure to high temperatures in the tropics. Developmental differences leading to leaf shape variation may be caused by fluctuations in auxin maxima along leaf lobes and margins, as seen in developmental studies of the model plant Arabidopsis thaliana (Nicotra et al., 2011, Kawamura et al., 2010).

Overall, limited morphological variation among the four regions in Panamá contrasts previous observations of morphological diversity observed in Costa Rica (Manshardt \& Zee, 
1994; Pérez et al., 2007; Brown et al., 2012). A few traits, such as leaf petiole color and leaf shape, varied significantly in both Panamá and Costa Rica; however, other traits, such as leaf teeth shape and petiole sinus shape did not vary significantly in Panamá, even though they were found to be significant in Costa Rica (Brown et al., 2012). The lack of morphological variation observed in Panamá may be, in part, due to smaller sampling sizes relative to the Costa Rican populations, in particular for fruit and reproductive traits; however, it could also be due to differences in regional differences in soil conditions, water availability and sun exposure between the countries.

Flower and fruit characteristics are said to be the most distinguishing and economically important in cultivated papaya (Moore, 2014). Cultivated papayas are hermaphroditic, and fruit shape (typically elongated) and flesh color (ranging from yellow to deep red), in particular, have been the targets of selection during domestication (OECD, 2005; Manshardt \& Zee, 1994). In Panamá, significant variation was observed in fruit flesh color, central cavity shape and seed color. Fruit flesh color observed in the wild correlates to previous observations made of wild papaya with flesh color consistently being yellow to orange (Manshardt \& Zee, 1994; d'Eeckenbrugge et al., 2007). None of the fruits collected exhibited red flesh color, which is a trait that was selected early on by domesticators (Manshardt \& Zee, 1994). Interestingly enough, fruits collected in the Western and Canal region of Panamá support previous observations of wild papaya fruit being small and golf ball-sized, or approximately $4.2 \mathrm{~cm}$ in diameter (Manshardt \& Zee, 1994). Similar sized fruit were found in the Northwest Pacific and Nicoya Peninsula of Costa Rica (Brown et al., 2012). The one fruit collected in the Southern region of Panamá was the largest fruit sampled, being a little larger than a tennis-ball, or approximately $6.6 \mathrm{~cm}$ in diameter and was more similar in size to what was found in the Central and Southern Pacific regions of Costa Rica (Brown et al., 2012). The central cavity of fruits collected in Panamá had thin mesocarps with cavities tightly packed with shriveled seeds, consistent with the wild phenotype. Previous studies on seed ecophysiology of cultivated and wild papaya identified wild seeds being about $30 \%$ smaller then domesticated seeds and had a shriveled appearance due to dormancy (OECD, 2005; Niklas \& Marler, 2007, Paz \& Vázques-Yanes, 1998).

Morphological observations with fruit size, flesh color, central cavity shape and seed appearance from Panamá contradicts previous predictions that the further south and west one travels in Central America towards South America there is a trend that papaya fruit are larger and 
pear-shaped, with red flesh and large seeds which are indicative of domesticated traits (Manshardt \& Zee, 1994; Paz \& Vázques-Yanes, 1998). Such a trend was observed in Costa Rica (Brown et al., 2012); however, this trend breaks down in Panamá. Papaya individuals in Panamá are more consistent with the typical wild type phenotype (small, seedy, yellow-fleshed fruit).

\section{Natural papaya populations exhibit moderate levels of diversity and regional variation in gene}

flow - The overwhelming similarity of morphological diversity among wild papaya populations in Panamá may not accurately reflect the underlying genetic diversity of these populations. We estimated slightly higher levels of genetic diversity in Panamá, with an overall average $H_{E}$ of 0.62, compared to previous results in Costa Rica, with an overall average $H_{E}$ of 0.57 (Brown et $a l ., 2012)$. Both of these diversity estimates are slightly lower than was reported for wild papaya populations in southern México (an average $H_{E}$ of 0.66 in fragmented habitats and 0.75 in continuous forests; Chaìvez-Pesqueira et al., 2014), but higher than the average $H_{E}$ of 0.41 reported for populations in the Caribbean and Pacific coasts of Costa Rica based on isozyme analysis (d'Eeckenbrugge et al., 2007).

Most regional populations in Panamá show a deficiency of observed heterozygosity relative to expected heterozygosity ( $F$, the fixation index, ranged between 0.17 and 0.20 ), consistent with previous observations in Costa Rica and Southern México (Brown et al., 2012; Chaìvez-Pesqueira et al., 2014). This is likely due to increased bi-parental inbreeding in Panamanian populations, as the inbreeding coefficient, $\mathrm{F}_{\mathrm{IS}}$, is relatively high for Panamanian populations $\left(\mathrm{F}_{\mathrm{IS}}=0.144\right)$. In México, fragmented populations had a higher $F$ than continuous forests, which we might expect if the isolation of these populations promoted higher incidences of inbreeding (Chaìvez-Pesqueira et al., 2014). This is contrary to some studies in Swietenia humilis that suggest habitat fragmentation may actually increase genetic exchange among populations by facilitating dispersal of pollen by long-distance (White et al., 2002). Panamá, like Costa Rica, exhibited deficiencies in heterozygosity with minimal deviation from HWE, but the fixation index was much lower in Panamanian populations compared to Costa Rican populations ( $F=0.20$ versus 0.42 respectively; Brown et al., 2012). The differences between the Panamá and Costa Rican samples could be due to differing degrees of habitat fragmentation, leading to more 
homogenized genotypes in Costa Rican wild papaya due to a greater restriction of gene flow and local inbreeding (Loveless \& Hamrick, 1984).

One notable exception in Panamá was the Northeastern region, where $H_{O}(0.70)$ was greater than $\mathrm{He}$ (0.62), though this difference was consistent with HWE for most loci. It was previously found in southern México that wild papaya populations had reductions in $H_{O}$ that were less severe in continuous forests relative to fragmented forests, though both populations still had reduced $H_{O}$ (Chaìvez-Pesqueira et al., 2014). The Northeastern region of Panamá was less fragmented, with only one major urban center (the city of Colón); thus, the landscape consisted more of continuous than fragmented forest. Consistent with our observations, this type of environment was shown to facilitate gene flow and outcrossing among populations in southern México (Chaìvez-Pesqueira et al., 2014). Studies in the fungus, Rhizoctonia solani, have indicated that populations with excess in heterozygosity could relate to higher fitness or outbreeding (Rosewich et al., 1999).

We observed moderate population differentiation among natural papaya regions in Panamá; overall $\mathrm{F}_{\mathrm{ST}}$ was 0.06 , while pairwise $\mathrm{F}_{\mathrm{ST}}$ values ranged from 0.035 and 0.21 . The most highly differentiated populations were between the Western and Northeastern regions (pairwise $\left.\mathrm{F}_{\mathrm{ST}}=0.21\right)$. Furthermore, these two populations are clearly differentiated in the PCoA analysis. This is likely due to their geographic separation, being at the two extremes of the sampled geographic distribution. Indeed, the Western region exhibits an increase in differentiation with increasing distance from the other regional populations. The least differentiated populations were those in the Canal and Southern regions; pair-wise $\mathrm{F}_{\mathrm{ST}}$ is 0.035 and individuals from both regions lack clear separation in the PCoA. This may be related to the geographic proximity in these populations. In addition, the Interamericana Highway connects these two populations, and most of the individuals in the South were found growing along this highway. It is possible that such a conduit may facilitate genetic exchange between these two regions.

It has been documented that sphingid moths (hawkmoths) are pollinators of dioecious papaya and are highly diverse in the Neotropics (Garrett, 1995; Martins \& Johnson, 2009) and Janzen (1981) confirmed that adult sphingids are able to go through two reproductive seasons in the tropical climate of Costa Rica. Garrett (1995) conducted a field study with sphingid moths pollinating cultivated dioecious papaya in Australia and confirmed Hyles lineata pollinated papaya in Australia. Many species of hawkmoths have a distribution in Central America and 
could potentially serve as a pollinator of wild dioecious papaya. Migratory events have been documented for several sphingid species in the tropics (Garrett, 1995), which could facilitate pollen exchange among individuals in the Canal and Southern regions. In a pollination ecology study between hawkmoths and cultivated papaya in Kenya it was also confirmed that hawkmoths cross-pollinate dioecious cultivated papaya (Martins \& Johnson; 2009).

Structure analysis supports the divergence of the Western and Northeastern regions, which are characterized by two distinct genetic clusters (clusters 2 and 3 respectively), consistent with separate genetic ancestries for these populations. The population in the Western region of Panamá is near the Costa Rican border, while the Northeastern region is closer to Colombia; the Panamá Canal separates both. Some individuals in the Northeast share ancestry with the predominant cluster found in the Western region, suggesting movement of papaya is more prevalent from the West to the East than vice versa.

Interestingly, the Canal region appears to be a "hot spot" for papaya diversity in Panamá. Individuals having shared ancestry with individuals from the Western and Northeastern regions (clusters 2 and 3), and one cluster unique to the Canal region (cluster 1), can be found there. There are also individuals with varying degrees of admixture between these different genotypes in the Canal region, more than was observed in the other regions. This may be due to either natural or artificial corridors for pollinators travelling large distances to collect pollen (White et al., 2002). For instance, the Panamá Canal is one of few sites left in the world with a forest corridor connecting the Pacific to the Atlantic (Condit et al., 2001), and that is of great importance when considering gene pool diversity, not just for papaya, but flora and fauna species overall. This landscape may have promoted the invasion of papaya as it is a pioneer species and prefers disturbed areas with light gaps. Artificial corridors promoting gene flow may be the Interamericana Highway, which crosses the country from west to east and the Transistmica Highway that links Panamá City to the city of Colón from south to north. At the same time, such corridors could pose a threat to the diversity of papaya by increasing gene transfer from crop-towild populations.

A recent expansion of natural papaya populations, particularly in the Southern and Canal regions, may also have contributed to greater gene flow among these regions. Demographic analyses of Panamá populations correlate to those found in Costa Rica, and support a bottleneck followed by an increase in population size. This is inferred from the significantly positive $\beta$ 
index, which is sensitive to recent population expansions, while the $k$ and $g$ tests are more sensitive to older expansions and were mostly insignificant. Therefore, it is most likely that for Panamanian papaya populations, the bottleneck and expansion are recent, perhaps coinciding with the influx of people migrating to urban cities; these people leave behind their small farms and pasture-lands, which allows these areas to revert back to their natural states (Condit et al., 2001). Papaya populations, having been reduced due to conversion of land for agriculture use, could have experienced a population expansion, invading abandoned fields and pastures in their role as early successional pioneer species.

\section{Minimal evidence of crop-to-wild gene flow exists for natural Panamanian papaya} populations - Observed heterozygosity is more reduced in cultivars (0.24) than in natural populations (overall average 0.55 ); however, $H_{E}$ in cultivars is very similar to the natural populations. A high $H_{E}$ in the cultivars suggests alleles have not been lost during domestication and that a domestication bottleneck had little effect on overall diversity. In some studies, it has been concluded that some cultivated perennial crops, such as olive, grapevine, and pistachio retain on average $95 \%$ of the genetic diversity existent in their wild counterparts (Miller \& Gross, 2011). Sixty-five percent of the loci in cultivars, however, deviated from HWE with a much lower fixation index than observed in natural populations, possibly due to a decrease in observed heterozygosity due to selective inbreeding of cultivar lines.

Population differentiation was greatest between the Western region and the cultivars, indicating minimal crop-to-wild gene flow in the West. This could be because the Western region was an isolated population, geographically distant from areas where cultivated papaya is being grown; also, this region was not near any densely populated city. The Northeastern, Canal and Southern regions had moderate levels of population differentiation with the cultivars. These regions are closer to populated urban areas, which may be facilitating genetic exchange between people's personal home gardens or even cultivated papaya plantations.

The extent of people's personal home gardens and the potential genetic exchange between wild papaya populations hasn't been thoroughly studied, but the PCoA indicated some evidence of gene exchange between cultivars and natural individuals. This was further confirmed with STRUCTURE; cultivars had several admixed individuals, although there was no clear trend among the unimproved and improved cultivars. An unimproved cultivar (HCAR14) from 
Panamá was distinctly different from the other cultivars, possibly indicating the unimproved cultivar was sampled from wild papaya populations. In contrast, two individuals from the Southern region and one individual from the Canal region share ancestry with the cultivars, and are likely instances where improved cultivars were introduced into the wild. Even though the genetic signature of cultivars is only infrequently observed in the natural regions throughout Panamá it provides support that there is some extent of crop-to-wild gene flow.

\section{CONCLUSION}

C. papaya from Panamá supports previous observations that wild papaya still exists in nature and we need to consider the implications of gene flow from local landraces into their wild-progenitors. Gene flow can be advantageous, potentially introducing new alleles into the populations; contrarily, gene flow from crops into wild plant populations can change the genetic material of the wild plant populations by homogenizing them to resemble more of the cultivated crop (Campbell et al., 2016). If the latter is true, we need to be cautious with cultivating crops because it can ultimately lead to diminishing the natural genetic biodiversity of crop wild progenitors. Further understanding of the structure and levels of genetic diversity in naturally occurring papaya throughout Mesoamerica will be important for their conservation and to protect the gene pool of wild individuals from crop-to-wild gene introgression. 


\section{LITERATURE CITED}

Aguilar, R., Quesada, M., Ashworth, L., Herrerias-Diego, Y., \& Lobo, J. (2008). Genetic consequences of habitat fragmentation in plant populations: susceptible signals in plant traits and methodological approaches. Molecular Ecology, 17: 5177-5188.

Arias, D. M., \& Rieseberg, L. H. (1994). Gene flow between cultivated and wild sunflowers. Theoretical and Applied Genetics, 89: 655-660.

Arrigo, N., Guadagnuolo, R., Lappe, S., Pasche, S., Parisod, C., \& Felber, F. (2011). Gene flow between wheat and wild relatives: empirical evidence from Aegilops geniculata, Ae. neglecta and Ae. triuncialis. Evolutionary Applications, 4: 685-695.

Amos, W., Hoffman, J. I., Frodsham, A., Zhang, L., Best, S., \& Hill, A. V. S. (2007). Automated binning of microsatellite alleles: problems and solutions. Molecular Ecology Notes, 7: 10-14.

Bilgin, R. (2007). Kgtests: a simple Excel Macro program to detect signatures of population expansion using microsatellites. Molecular Ecology Notes, 7: 416-417.

Brown, J. E., Bauman, J. M., Lawrie, J. F., Rocha, O. J., \& Moore, R. C. (2012). The structure of morphological and genetic diversity in natural populations of Carica papaya (Caricaceae) in Costa Rica. Biotropica, 44: 179-188.

Brown, T. A., Jones, M. K., Powell, W., \& Allaby, R. G. (2009). The complex origins of domesticated crops in the Fertile Crescent. Trends in Ecology \& Evolution, 24: 103-109.

Burke, J. M., Gardner, K. A., \& Rieseberg, L. H. (2002). The potential for gene flow between cultivated and wild sunflower (Helianthus annuus) in the United States. American Journal of Botany, 89: 1550-1552.

Campbell, L. G., Lee, D., Shukla, K., Waite, T. A., \& Bartsch, D. (2016). An ecological approach to measuring the evolutionary consequences of gene flow from crops to wild or weedy relatives. Applications in Plant Sciences, 4: 1500114.

Carvalho, F. A., \& Renner, S. S. (2012). A dated phylogeny of the papaya family (Caricaceae) reveals the crop's closest relatives and the family's biogeographic history. Molecular Phylogenetics and Evolution, 65: 46-53.

Cespedes, M., Gutierrez, M. V., Holbrook, N. M., \& Rocha, O. J. (2003). Restoration of genetic diversity in the dry forest tree Swietenia macrophylla (Meliaceae) after pasture abandonment in Costa Rica. Molecular Ecology, 12: 3201-3212. 
Chávez-Pesqueira, M., Suárez-Montes, P., Castillo, G., \& Núñez-Farfán, J. (2014). Habitat fragmentation threatens wild populations of Carica papaya (Caricaceae) in a lowland rainforest. American Journal of Botany, 101: 1092-1101.

Chen, C., Yu, Q., Hou, S., Li, Y., Eustice, M., Skelton, R. L., Veatch, O., Herdes, R. E., Diebold, L., Saw, J., Feng, Y., Qian, W., Bynum, L., Wang, L., Moore, P. H., Paull, R. E., Alam, M., \& Ming, R. (2007). Construction of a sequence-tagged high-density genetic map of papaya for comparative structural and evolutionary genomics in Brassicales. Genetics, 177: 2481-2491.

Condit, R., Robinson, W. D., Ibáñez, R., Aguilar, S., Sanjur, A., Martínez, R., Stallard, R. F., García, T., Angehr, G. R., Petit, L., Wright, S. J., Robinson, T. R., \& Heckadon, S. (2001). The Status of the Panama Canal Watershed and Its Biodiversity at the Beginning of the 21st Century. BioScience, 51: 389-398.

d'Eeckenbrugge, G. C., Restrepo, M. T., Jiménez, D., \& Mora, E. (2007). Morphological and isozyme characterization of common papaya in Costa Rica. In I International Symposium on Papaya 740: 109-120.

Deroles, S. (2009). Anthocyanin biosynthesis in plant cell cultures: A potential source of natural colourants. C. Winefield, K. Davies, \& K. Gould (Eds), In Anthocyanins (pp. 108-167) New York, NY: Springer.

Delplancke, M., Alvarez, N., Espíndola, A., Joly, H., Benoit, L., Brouck, E., \& Arrigo, N. (2012). Gene flow among wild and domesticated almond species: insights from chloroplast and nuclear markers. Evolutionary Applications, 5: 317-329.

Doebley, J. F., Gaut, B. S., \& Smith, B. D. (2006). The molecular genetics of crop domestication. Cell, 127: 1309-1321.

Earl, D. A., vonHoldt, B.M. (2012). STRUCTURE HARVESTER: a website and program for visualizing STRUCTURE output and implementing the Evanno method. Conservation Genetics Resources, 4: 359-361.

Ellstrand, N. C., \& Elam, D. R. (1993). Population genetic consequences of small population size: implications for plant conservation. Annual Review of Ecology and Systematics, 24: 217-242.

Ellstrand, N. C., Prentice, H. C., \& Hancock, J. F. (1999). Gene flow and introgression from 
domesticated plants into their wild relatives. Annual Review of Ecology and Systematics, 30: 539-563.

Excoffier, L., Laval, G., \& Schneider, S. (2005) Arlequin (ver. 3.0): An integrated software package for population genetics data analysis. Evolutionary Bioinformatics Online, 1: 4750.

Excoffier, L., \& Lischer, H. E. (2010). Arlequin suite (ver 3.5): a new series of programs to perform population genetics analyses under Linux and Windows. Molecular Ecology Resources, 10: 564-567.

Excoffier, L., Smouse, P. E., \& Quattro, J. M. (1992). Analysis of molecular variance inferred from metric distances among DNA haplotypes: application to human mitochondrial DNA restriction data. Genetics, 131: 479-491.

Evans, E. A., \& Ballen, F. H. (2012). An overview of global papaya production, trade, and consumption. Gainesville: University of Florida.

Evanno, G., Regnaut, S., \& Goudet, J. (2005). Detecting the number of clusters of individuals using the software STRUCTURE: a simulation study. Molecular Ecology, 14: 26112620.

Falush, D., Stephens, M., \& Pritchard, J. K. (2007). Inference of population structure using multilocus genotype data: dominant markers and null alleles. Molecular Ecology Notes, 7: 574-578.

Garrett, A. (1995). The pollination biology of papaw (Carica papaya L.) in Central Queensland (Thesis). Retrieved from ACQUIRE-CQUniversity’s Institutional Repository. (Accession No. 10018/25774).

Garza, J. C., \& Williamson, E. G. (2001). Detection of reduction in population size using data from microsatellite loci. Molecular Ecology, 10: 305-318.

Guo, S. W., \& Thompson, E. A. (1992). Performing the exact test of Hardy-Weinberg proportion for multiple alleles. Biometrics, 48: 361-372.

Hamrick, J. L., \& Murawski, D. A. (1991). Levels of allozyme diversity in populations of uncommon neotropical tree species. Journal of Tropical Ecology, 7: 395-399.

Holderegger, R., Kamm, U., \& Gugerli, F. (2006). Adaptive vs. neutral genetic diversity: implications for landscape genetics. Landscape Ecology, 21: 797-807.

International Board for Plant Genetic Resources [IBPGR]. (1988). Descriptors for 
Papaya. International Board for Plant Genetic Resources, Rome, Italy

Janzen, D. H. (1981). Patterns of herbivory in a tropical deciduous forest. Biotropica, 13: 271282.

Kawamura, E., Horiguchi, G., \& Tsukaya, H. (2010). Mechanisms of leaf tooth formation in Arabidopsis. The Plant Journal, 62: 429-441.

Kim, M. S., Moore, P. H., Zee, F., Fitch, M. M. M., Steiger, D. L., Manshardt, R. M., Paull, R. E., Drew, R. A., Sekioka, T., \& Ming, R. (2002). Genetic diversity of Carica papaya as revealed by AFLP markers. Genome, 45: 503-512.

Kimmel, M., Chakraborty, R., King, J. P., Bamshad, M., Watkins, W. S., \& Jorde, L. B. (1998). Signatures of population expansion in microsatellite repeat data. Genetics, 148: 19211930.

King, J. P., Kimmel, M., \& Chakraborty, R. (2000). A power analysis of microsatellite-based statistics for inferring past population growth. Molecular Biology and Evolution, 17: 1859-1868.

Klich, M. G. (2000). Leaf variations in Elaeagnus angustifolia related to environmental heterogeneity. Environmental and Experimental Botany, 44: 171-183.

Konczak, I., \& Zhang, W. (2004). Anthocyanins-more than nature's colours. BioMed Research International, 2004: 239-240.

Loveless, M. D., \& Hamrick, J. L. (1984). Ecological determinants of genetic structure in plant populations. Annual Review of Ecology and Systematics, 15: 65-95.

Manshardt, R. M., \& Zee, F. T.-P. (1994). Papaya germplasm and breeding in Hawaii. Fruit Varieties Journal (USA), 48: 146-152

Martins, D. J., \& Johnson, S. D. (2009). Distance and quality of natural habitat influence hawkmoth pollination of cultivated papaya. International Journal of Tropical Insect Science, 29: 114-123.

Miller, A. J., \& Gross, B. L. (2011). From forest to field: perennial fruit crop domestication. American Journal of Botany, 98: 1389-1414.

Ming, R., Yu, Q., Moore, P. H., Paull, R. E., Chen, N. J., Wang, M. L., Zhu, Y. J., Schuler, M. A., Jiang, J., \& Paterson, A. H. (2012). Genome of papaya, a fast growing tropical fruit tree. Tree Genetics \& Genomes, 8: 445-462. 
Moore, P. H. (2014). Phenotypic and Genetic Diversity of Papaya. In R. Ming \& P.H. Moore (Eds.), Genetics and Genomics of Papaya (pp. 35-45). New York, NY: Springer.

Nakasone, H. Y., \& Paull, R. E. (1998). Tropical fruits. Wallingford, UK: Cab International.

Nason, J. D., \& Hamrick, J. L. (1997). Reproductive and genetic consequences of forest fragmentation: two case studies of neotropical canopy trees. Journal of Heredity, 88: 264276.

Nicotra, A. B., Leigh, A., Boyce, C. K., Jones, C. S., Niklas, K. J., Royer, D. L., \& Tsukaya, H. (2011). The evolution and functional significance of leaf shape in the angiosperms. Functional Plant Biology, 38: 535-552.

Niklas, K. J., \& Marler, T. E. (2007). Carica papaya (Caricaceae): a case study into the effects of domestication on plant vegetative growth and reproduction. American Journal of Botany, 94: 999-1002.

Organisation for Economic Co-operation and Development [OECD]. (2005). Consensus document on the biology of papaya (Carica papaya). Series on Harmonisation of Regulatory Oversight in Biotechnology No.33.

Paz, L., \& Vázquez-Yanes, C. (1998). Comparative seed ecophysiology of wild and cultivated Carica papaya trees from a tropical rain forest region in Mexico. Tree Physiology, 18: 277-280.

Peakall, R., \& Smouse, P. E. (2006). GenAlEx 6: genetic analysis in Excel. Population genetic software for teaching and research. Molecular Ecology Notes, 6: 288-295.

Peakall, R., \& Smouse, P. E. (2012). GenAlEx 6: genetic analysis in Excel. Population genetic software for teaching and research - an update. Bioinformatics, 28: 2537-2539.

Pérez, J. O., d'Eeckenbrugge, G. C., Risterucci, A. M., Dambier, D., \& Ollitrault, P. (2007). Papaya genetic diversity assessed with microsatellite markers in germplasm from the Caribbean region, In Proceedings of the $1^{\text {st }}$ International Symposium on Papaya, 740: 93101.

Pritchard, J. K., Stephens, M., \& Donnelly, P. (2000). Inference of population structure using multilocus genotype data. Genetics, 155: 945-959.

Reich, D. E., \& Goldstein, D. B. (1998). Genetic evidence for a Paleolithic human population expansion in Africa. Proceedings of the National Academy of Sciences, 95: 8119-8123.

Reich, D. E., Feldman, M. W., \& Goldstein, D. B. (1999). Statistical properties of two tests that 
use multilocus data sets to detect population expansions. Molecular Biology and Evolution, 16: 453-466.

Rocha, O. J., \& Aguilar, G. (2001). Variation in the breeding behavior of the dry forest tree Enterolobium cyclocarpum (Guanacaste) in Costa Rica. American Journal of Botany, 88: $1600-1606$.

Rompré, G., Robinson, W. D., \& Desrochers, A. (2008). Causes of habitat loss in a Neotropical landscape: The Panama Canal corridor. Landscape and Urban Planning, 87: 129-139.

Rudel, T., \& Roper, J. (1997). The paths to rain forest destruction: crossnational patterns of tropical deforestation, 1975-1990. World Development, 25: 53-65.

Rosenberg, N. A. (2004). DISTRUCT: a program for the graphical display of population structure. Molecular Ecology Notes, 4: 137-138.

Rosewich, U. L., Pettway, R. E., McDonald, B. A., \& Kistler, H. C. (1999). High levels of gene flow and heterozygote excess characterize Rhizoctonia solani AG-1 IA (Thanatephorus cucumeris) from Texas. Fungal Genetics and Biology, 28: 148-159.

SAS Institute Inc. 2009 JMP 8 Statistics and Graphics Guide, Second Edition. Cary, NC: SAS Institute Inc.

SAS Institute Inc. 2013. Using JMP 11. Cary, NC: SAS Institute Inc.

Svenning, J. C., Engelbrecht, B. M., Kinner, D. A., Kursar, T. A., Stallard, R. F., \& Wright, S. J. (2006). The relative roles of environment, history and local dispersal in controlling the distributions of common tree and shrub species in a tropical forest landscape, Panama. Journal of Tropical Ecology, 22: 575-586.

Trucco, F., Tatum, T., Rayburn, A. L., \& Tranel, P. J. (2009). Out of the swamp: unidirectional hybridization with weedy species may explain the prevalence of Amaranthus tuberculatus as a weed. New Phytologist, 184: 819-827.

White, G. M., Boshier, D. H., \& Powell, W. (2002). Increased pollen flow counteracts fragmentation in a tropical dry forest: an example from Swietenia humilis Zuccarini. Proceedings of the National Academy of Sciences, 99: 2038-2042.

Wright, S. (1965). The interpretation of population structure by F-statistics with special regard to systems of mating. Evolution, 19: 395-420.

Young, A., Boyle, T., \& Brown, T. (1996). The population genetic consequences of habitat fragmentation for plants. Trends in Ecology \& Evolution, 11: 413-418. 
Table 1. Geographic coordinates of Panama individuals sampled in Panamá and location of voucher specimen (Willard Sherman Turrell Herbarium at Miami University [MU] and Smithsonian Tropical Research Institute in Panama [STRI]).

\begin{tabular}{|c|c|c|c|}
\hline & & & Voucher Specimen \\
\hline Accession & Location & Region & Location \\
\hline $\mathrm{Pa} 1$ & $8^{\circ} 42^{\prime} 3.96^{\prime \prime} \mathrm{N}, 79^{\circ} 52^{\prime} 13.02^{\prime \prime} \mathrm{W}$ & South & MU \\
\hline $\mathrm{Pa} 2$ & $8^{\circ} 42^{\prime} 5.94^{\prime \prime} \mathrm{N}, 79^{\circ} 52^{\prime} 17.94^{\prime \prime} \mathrm{W}$ & South & MU \\
\hline $\mathrm{Pa} 4$ & $8^{\circ} 32^{\prime} 40.56^{\prime \prime} \mathrm{N}, 7^{\circ} 54^{\prime} 46.32^{\prime \prime} \mathrm{W}$ & South & \\
\hline Pa11 & $8^{\circ} 30^{\prime} 35.28^{\prime \prime} \mathrm{N}, 80^{\circ} 20^{\prime} 29.28^{\prime \prime} \mathrm{W}$ & South & MU, STRI \\
\hline $\mathrm{Pa} 12$ & $8^{\circ} 25^{\prime} 25.56^{\prime \prime} \mathrm{N}, 80^{\circ} 30^{\prime} 8.88^{\prime \prime} \mathrm{W}$ & South & MU \\
\hline Pa13 & $8^{\circ} 25^{\prime} 24.00^{\prime \prime} \mathrm{N}, 80^{\circ} 30^{\prime} 10.50^{\prime \prime} \mathrm{W}$ & South & MU \\
\hline Pa14 & $8^{\circ} 45^{\prime} 42.06^{\prime \prime} \mathrm{N}, 7^{\circ} 52^{\prime} 36.42^{\prime \prime} \mathrm{W}$ & South & MU \\
\hline $\mathrm{Pa} 70$ & $8^{\circ} 6^{\prime} 33.90^{\prime \prime} \mathrm{N}, 80^{\circ} 45^{\prime} 48.42^{\prime \prime} \mathrm{W}$ & South & \\
\hline Pa71 & $8^{\circ} 6^{\prime} 33.90^{\prime \prime} \mathrm{N}, 80^{\circ} 45^{\prime} 48.42^{\prime \prime} \mathrm{W}$ & South & \\
\hline $\mathrm{Pa} 72$ & $8^{\circ} 6^{\prime} 33.90^{\prime \prime} \mathrm{N}, 80^{\circ} 45^{\prime} 48.42^{\prime \prime} \mathrm{W}$ & South & \\
\hline $\mathrm{Pa} 73$ & $8^{\circ} 6^{\prime} 33.90^{\prime \prime} \mathrm{N}, 80^{\circ} 45^{\prime} 48.42^{\prime \prime} \mathrm{W}$ & South & \\
\hline $\mathrm{Pa} 74$ & $8^{\circ} 6^{\prime} 33.90^{\prime \prime} \mathrm{N}, 80^{\circ} 45^{\prime} 48.42^{\prime \prime} \mathrm{W}$ & South & \\
\hline Pa75 & $8^{\circ} 6^{\prime} 33.90^{\prime \prime} \mathrm{N}, 80^{\circ} 45^{\prime} 48.42^{\prime \prime} \mathrm{W}$ & South & \\
\hline Pa5 & $8^{\circ} 23^{\prime} 54.66^{\prime \prime} \mathrm{N}, 82^{\circ} 19^{\prime} 17.16^{\prime \prime} \mathrm{W}$ & West & MU \\
\hline $\mathrm{Pa} 6$ & $8^{\circ} 56^{\prime} 39.12^{\prime \prime} \mathrm{N}, 82^{\circ} 8^{\prime} 33.12^{\prime \prime} \mathrm{W}$ & West & MU \\
\hline $\mathrm{Pa} 7$ & $8^{\circ} 56^{\prime} 37.92^{\prime \prime} \mathrm{N}, 82^{\circ} 9^{\prime} 51.72^{\prime \prime} \mathrm{W}$ & West & \\
\hline Pa8_1 & $8^{\circ} 56^{\prime} 43.20^{\prime \prime} \mathrm{N}, 82^{\circ} 8^{\prime} 42.96^{\prime \prime} \mathrm{W}$ & West & \\
\hline Pa8_2 & $8^{\circ} 56^{\prime} 43.20^{\prime \prime} \mathrm{N}, 82^{\circ} 8^{\prime} 42.96^{\prime \prime} \mathrm{W}$ & West & MU \\
\hline $\mathrm{Pa} 9$ & $8^{\circ} 56^{\prime} 34.62^{\prime \prime} \mathrm{N}, 82^{\circ} 8^{\prime} 36.18^{\prime \prime} \mathrm{W}$ & West & \\
\hline Pa10 & $8^{\circ} 13^{\prime} 16.62^{\prime \prime} \mathrm{N}, 81^{\circ} 45^{\prime} 2.28^{\prime \prime} \mathrm{W}$ & West & STRI \\
\hline Pa55 & $8^{\circ} 56^{\prime} 34.62^{\prime \prime} \mathrm{N}, 82^{\circ} 8^{\prime} 36.18^{\prime \prime} \mathrm{W}$ & West & \\
\hline Pa68 & $8^{\circ} 56^{\prime} 31.92^{\prime \prime} \mathrm{N}, 82^{\circ} 8^{\prime} 40.08^{\prime \prime} \mathrm{W}$ & West & \\
\hline Pa69 & $8^{\circ} 56^{\prime} 38.52^{\prime \prime} \mathrm{N}, 82^{\circ} 8^{\prime} 34.32^{\prime \prime} \mathrm{W}$ & West & \\
\hline $\mathrm{Pa} 25$ & $9^{\circ} 32^{\prime} 18.24^{\prime \prime} \mathrm{N}, 79^{\circ} 40^{\prime} 25.93 " \mathrm{~W}$ & Northeast & MU, STRI \\
\hline $\mathrm{Pa} 26$ & $9^{\circ} 32^{\prime} 18.24^{\prime \prime} \mathrm{N}, 79^{\circ} 40^{\prime} 25.93 " \mathrm{~W}$ & Northeast & MU \\
\hline
\end{tabular}




\begin{tabular}{|c|c|c|c|}
\hline $\mathrm{Pa} 27$ & $9^{\circ} 32^{\prime} 18.24^{\prime \prime} \mathrm{N}, 79^{\circ} 40^{\prime} 25.93^{\prime \prime} \mathrm{W}$ & Northeast & STRI \\
\hline $\mathrm{Pa} 28$ & $9^{\circ} 32^{\prime} 18.24^{\prime \prime} \mathrm{N}, 79^{\circ} 40^{\prime} 25.93^{\prime \prime} \mathrm{W}$ & Northeast & MU, STRI \\
\hline $\mathrm{Pa} 29$ & $9^{\circ} 32^{\prime} 18.24^{\prime \prime} \mathrm{N}, 79^{\circ} 40^{\prime} 25.93^{\prime \prime} \mathrm{W}$ & Northeast & \\
\hline $\mathrm{Pa} 30$ & $9^{\circ} 32^{\prime} 18.24^{\prime \prime} \mathrm{N}, 79^{\circ} 40^{\prime} 25.93^{\prime \prime} \mathrm{W}$ & Northeast & \\
\hline Pa31 & $9^{\circ} 32^{\prime} 18.24^{\prime \prime} \mathrm{N}, 79^{\circ} 40^{\prime} 25.93 " \mathrm{~W}$ & Northeast & \\
\hline Pa32 & $9^{\circ} 30^{\prime} 46.38^{\prime \prime} \mathrm{N}, 79^{\circ} 41^{\prime} 23.46^{\prime \prime} \mathrm{W}$ & Northeast & \\
\hline $\mathrm{Pa} 33$ & $9^{\circ} 30^{\prime} 46.38^{\prime \prime} \mathrm{N}, 79^{\circ} 41^{\prime} 23.46^{\prime \prime} \mathrm{W}$ & Northeast & MU, STRI \\
\hline Pa58 & $9^{\circ} 30^{\prime} 46.38^{\prime \prime} \mathrm{N}, 79^{\circ} 41^{\prime} 23.46^{\prime \prime} \mathrm{W}$ & Northeast & \\
\hline Pa15 & $9^{\circ} 4^{\prime} 44.52^{\prime \prime} \mathrm{N}, 79^{\circ} 39^{\prime} 45.78^{\prime \prime} \mathrm{W}$ & Canal & MU \\
\hline Pa16 & $9^{\circ} 4^{\prime} 44.52^{\prime \prime} \mathrm{N}, 79^{\circ} 39^{\prime} 45.78^{\prime \prime} \mathrm{W}$ & Canal & MU, STRI \\
\hline Pa17 & $9^{\circ} 5^{\prime} 57.24^{\prime \prime} \mathrm{N}, 79^{\circ} 40^{\prime} 52.68^{\prime \prime} \mathrm{W}$ & Canal & MU, STRI \\
\hline Pa18 & $9^{\circ} 5^{\prime} 57.24^{\prime \prime} \mathrm{N}, 79^{\circ} 40^{\prime} 52.68^{\prime \prime} \mathrm{W}$ & Canal & MU \\
\hline Pa19 & $9^{\circ} 6^{\prime} 43.08^{\prime \prime} \mathrm{N}, 79^{\circ} 41^{\prime} 31.92^{\prime \prime} \mathrm{W}$ & Canal & MU, STRI \\
\hline $\mathrm{Pa} 20$ & $9^{\circ} 6^{\prime} 42.00^{\prime \prime} \mathrm{N}, 79^{\circ} 41^{\prime} 20.64^{\prime \prime} \mathrm{W}$ & Canal & MU, STRI \\
\hline $\mathrm{Pa} 21$ & $9^{\circ} 4^{\prime} 3.72^{\prime \prime} \mathrm{N}, 79^{\circ} 39^{\prime} 10.68^{\prime \prime} \mathrm{W}$ & Canal & MU \\
\hline $\mathrm{Pa} 22$ & $9^{\circ} 4^{\prime} 44.52^{\prime \prime} \mathrm{N}, 79^{\circ} 39^{\prime} 45.78^{\prime \prime} \mathrm{W}$ & Canal & MU \\
\hline $\mathrm{Pa} 23$ & $9^{\circ} 4^{\prime} 44.52^{\prime \prime} \mathrm{N}, 79^{\circ} 39^{\prime} 45.78^{\prime \prime} \mathrm{W}$ & Canal & MU, STRI \\
\hline $\mathrm{Pa} 24$ & $9^{\circ} 7^{\prime} 14.64^{\prime \prime} \mathrm{N}, 79^{\circ} 42^{\prime} 54.42^{\prime \prime} \mathrm{W}$ & Canal & MU, STRI \\
\hline $\mathrm{Pa} 34$ & $9^{\circ} 7^{\prime} 40.67^{\prime \prime} \mathrm{N}, 79^{\circ} 36^{\prime} 54.69^{\prime \prime} \mathrm{W}$ & Canal & MU \\
\hline Pa35 & $9^{\circ} 4^{\prime} 45.54^{\prime \prime} \mathrm{N}, 79^{\circ} 37^{\prime} 28.92^{\prime \prime} \mathrm{W}$ & Canal & \\
\hline Pa36 & $9^{\circ} 1^{\prime} 10.56^{\prime \prime} \mathrm{N}, 79^{\circ} 36^{\prime} 44.10^{\prime \prime} \mathrm{W}$ & Canal & MU, STRI \\
\hline $\mathrm{Pa} 37$ & $9^{\circ} 1^{\prime} 10.56^{\prime \prime} \mathrm{N}, 79^{\circ} 36^{\prime} 44.10^{\prime \prime} \mathrm{W}$ & Canal & MU, STRI \\
\hline Pa38 & $9^{\circ} 1^{\prime} 6.06^{\prime \prime} \mathrm{N}, 79^{\circ} 36^{\prime} 35.94 " \mathrm{~W}$ & Canal & \\
\hline Pa39 & $9^{\circ} 1^{\prime} 6.06^{\prime \prime} \mathrm{N}, 79^{\circ} 36^{\prime} 35.94^{\prime \prime} \mathrm{W}$ & Canal & MU, STRI \\
\hline $\mathrm{Pa} 40$ & $9^{\circ} 1^{\prime} 6.06^{\prime \prime} \mathrm{N}, 79^{\circ} 36^{\prime} 35.94^{\prime \prime} \mathrm{W}$ & Canal & MU, STRI \\
\hline Pa41 & $9^{\circ} 1^{\prime} 6.06^{\prime \prime} \mathrm{N}, 79^{\circ} 36^{\prime} 35.94 " \mathrm{~W}$ & Canal & MU, STRI \\
\hline $\mathrm{Pa} 42$ & $9^{\circ} 1^{\prime} 6.06^{\prime \prime} \mathrm{N}, 79^{\circ} 36^{\prime} 35.94^{\prime \prime} \mathrm{W}$ & Canal & MU, STRI \\
\hline $\mathrm{Pa} 43$ & $9^{\circ} 0^{\prime} 22.26^{\prime \prime} \mathrm{N}, 79^{\circ} 35^{\prime} 36.66^{\prime \prime} \mathrm{W}$ & Canal & MU, STRI \\
\hline $\mathrm{Pa} 44$ & $9^{\circ} 1^{\prime} 6.06 " \mathrm{~N}, 79^{\circ} 36^{\prime} 35.94^{\prime \prime} \mathrm{W}$ & Canal & MU, STRI \\
\hline $\mathrm{Pa} 45$ & $9^{\circ} 1^{\prime} 6.06^{\prime \prime} \mathrm{N}, 79^{\circ} 36^{\prime} 35.94^{\prime \prime} \mathrm{W}$ & Canal & MU \\
\hline $\mathrm{Pa} 46$ & $9^{\circ} 0^{\prime} 19.44^{\prime \prime} \mathrm{N}, 79^{\circ} 35^{\prime} 31.98^{\prime \prime} \mathrm{W}$ & Canal & \\
\hline
\end{tabular}




\begin{tabular}{|c|c|c|c|}
\hline $\mathrm{Pa} 47$ & $9^{\circ} 0^{\prime} 19.44^{\prime \prime} \mathrm{N}, 79^{\circ} 35^{\prime} 31.98^{\prime \prime} \mathrm{W}$ & Canal & MU, STRI \\
\hline $\mathrm{Pa} 48$ & $9^{\circ} 0^{\prime} 19.44^{\prime \prime} \mathrm{N}, 79^{\circ} 35^{\prime} 31.98^{\prime \prime} \mathrm{W}$ & Canal & \\
\hline $\mathrm{Pa} 49$ & $9^{\circ} 0^{\prime} 19.44^{\prime \prime} \mathrm{N}, 79^{\circ} 35^{\prime} 31.98^{\prime \prime} \mathrm{W}$ & Canal & MU \\
\hline $\mathrm{Pa} 50$ & $9^{\circ} 0^{\prime} 19.44^{\prime \prime} \mathrm{N}, 79^{\circ} 35^{\prime} 31.98^{\prime \prime} \mathrm{W}$ & Canal & \\
\hline Pa51 & $9^{\circ} 0^{\prime} 19.44^{\prime \prime} \mathrm{N}, 79^{\circ} 35^{\prime} 31.98^{\prime \prime} \mathrm{W}$ & Canal & MU \\
\hline $\mathrm{Pa} 52$ & $9^{\circ} 0^{\prime} 19.44^{\prime \prime} \mathrm{N}, 79^{\circ} 35^{\prime} 31.98^{\prime \prime} \mathrm{W}$ & Canal & MU, STRI \\
\hline Pa53 & $9^{\circ} 0^{\prime} 19.44^{\prime \prime} \mathrm{N}, 79^{\circ} 35^{\prime} 31.98^{\prime \prime} \mathrm{W}$ & Canal & \\
\hline $\mathrm{Pa} 54$ & $9^{\circ} 4^{\prime} 44.52^{\prime \prime} \mathrm{N}, 79^{\circ} 39^{\prime} 45.78^{\prime \prime} \mathrm{W}$ & Canal & \\
\hline Pa56 & $9^{\circ} 4^{\prime} 44.52^{\prime \prime} \mathrm{N}, 79^{\circ} 39^{\prime} 45.78^{\prime \prime} \mathrm{W}$ & Canal & \\
\hline $\mathrm{Pa} 57$ & $9^{\circ} 4^{\prime} 44.52^{\prime \prime} \mathrm{N}, 79^{\circ} 39^{\prime} 45.78^{\prime \prime} \mathrm{W}$ & Canal & \\
\hline Pa59 & $9^{\circ} 7^{\prime} 5.58^{\prime \prime} \mathrm{N}, 79^{\circ} 41^{\prime} 50.28^{\prime \prime} \mathrm{W}$ & Canal & \\
\hline $\mathrm{Pa} 60$ & $9^{\circ} 1^{\prime} 6.06^{\prime \prime} \mathrm{N}, 79^{\circ} 36^{\prime} 35.94 " \mathrm{~W}$ & Canal & \\
\hline Pa61 & $9^{\circ} 1^{\prime} 6.06^{\prime \prime} \mathrm{N}, 79^{\circ} 36^{\prime} 35.94 " \mathrm{~W}$ & Canal & \\
\hline $\mathrm{Pa} 62$ & $9^{\circ} 1^{\prime} 6.06 " \mathrm{~N}, 79^{\circ} 36^{\prime} 35.94 " \mathrm{~W}$ & Canal & \\
\hline $\mathrm{Pa} 63$ & $9^{\circ} 1^{\prime} 6.06^{\prime \prime} \mathrm{N}, 79^{\circ} 36^{\prime} 35.94^{\prime \prime} \mathrm{W}$ & Canal & \\
\hline $\mathrm{Pa} 64$ & $9^{\circ} 1^{\prime} 6.06^{\prime \prime} \mathrm{N}, 79^{\circ} 36^{\prime} 35.94^{\prime \prime} \mathrm{W}$ & Canal & \\
\hline Pa65 & $8^{\circ} 59^{\prime} 22.20^{\prime \prime} \mathrm{N}, 79^{\circ} 34^{\prime} 42.36^{\prime \prime} \mathrm{W}$ & Canal & \\
\hline Pa66 & $9^{\circ} 0^{\prime} 22.26^{\prime \prime} \mathrm{N}, 79^{\circ} 35^{\prime} 36.66^{\prime \prime} \mathrm{W}$ & Canal & \\
\hline $\mathrm{Pa} 67$ & $9^{\circ} 7^{\prime} 5.16^{\prime \prime} \mathrm{N}, 79^{\circ} 41^{\prime} 49.20^{\prime \prime} \mathrm{W}$ & Canal & \\
\hline $\mathrm{Pa} 76$ & $9^{\circ} 7^{\prime} 5.58^{\prime \prime} \mathrm{N}, 79^{\circ} 41^{\prime} 50.28^{\prime \prime} \mathrm{W}$ & Canal & \\
\hline $\mathrm{Pa} 77$ & $9^{\circ} 7^{\prime} 5.58^{\prime \prime} \mathrm{N}, 79^{\circ} 41^{\prime} 50.28^{\prime \prime} \mathrm{W}$ & Canal & \\
\hline $\mathrm{Pa} 78$ & $9^{\circ} 7^{\prime} 5.58^{\prime \prime} \mathrm{N}, 79^{\circ} 41^{\prime} 50.28^{\prime \prime} \mathrm{W}$ & Canal & \\
\hline $\mathrm{Pa} 79$ & $9^{\circ} 7^{\prime} 5.58^{\prime \prime} \mathrm{N}, 79^{\circ} 41^{\prime} 50.28^{\prime \prime} \mathrm{W}$ & Canal & \\
\hline $\mathrm{Pa} 80$ & $9^{\circ} 5^{\prime} 57.24^{\prime \prime} \mathrm{N}, 79^{\circ} 40^{\prime} 52.68^{\prime \prime} \mathrm{W}$ & Canal & \\
\hline $\mathrm{Pa} 81$ & $9^{\circ} 4^{\prime} 44.52^{\prime \prime} \mathrm{N}, 79^{\circ} 39^{\prime} 45.78^{\prime \prime} \mathrm{W}$ & Canal & \\
\hline $\mathrm{Pa} 82$ & $9^{\circ} 4^{\prime} 44.52^{\prime \prime} \mathrm{N}, 79^{\circ} 39^{\prime} 45.78^{\prime \prime} \mathrm{W}$ & Canal & \\
\hline
\end{tabular}


Table 2. Cultivar names, accessions and place of origin.

\begin{tabular}{|c|c|c|c|c|}
\hline \multirow[b]{3}{*}{ Name $^{\mathrm{a}}$} & \multirow[b]{3}{*}{ Accession } & \multicolumn{2}{|l|}{ Improved or } & \multirow[b]{3}{*}{ Origin } \\
\hline & & Unimproved & Mating & \\
\hline & & Cultivar ${ }^{\mathrm{b}}$ & System & \\
\hline \multirow[t]{2}{*}{ 928_M } & UH928 & Unimproved & Dioecious & Rio Terraba, near Paso \\
\hline & & & & Real, Costa Rica \\
\hline H11_F & HCAR 11 & Improved & Gynodioecious & Hawaii, United States \\
\hline H16_F & HCAR 16 & Unimproved & Gynodioecious & Malaysia \\
\hline HCAR_F & HCAR 14 & Unimproved & Gynodioecious & Panamá \\
\hline SUNUP_H & SunUp & Improved & Gynodioecious & Hawaii, United States \\
\hline H302_F & & Improved & Gynodioecious & Hawaii, United States \\
\hline CO_H & Coimbatore 7 & Improved & Gynodioecious & Coimbatore, India \\
\hline H196 & & Improved & Gynodioecious & Hawaii, United States \\
\hline 918_H & UH 918 & Unimproved & Gynodioecious & Orotina, Costa Rica \\
\hline H207_F & HCAR 207 & Improved & Gynodioecious & Taiwan \\
\hline \multirow[t]{2}{*}{ NO31_F } & NO3-1 & Improved & Gynodioecious & Hawaii, United States \\
\hline & & & & (originally from Cuba) \\
\hline \multirow[t]{2}{*}{ DREW_M } & Drew & Improved & Dioecious & S.E. Queensland, \\
\hline & & & & Australia \\
\hline KAEK & HCAR 13 & Improved & Gynodioecious & Thailand \\
\hline \multicolumn{5}{|l|}{ DUM_H } \\
\hline \multirow[t]{2}{*}{ H164_F } & HCAR 164 & Improved & Dioecious & Colombia, via Florida, \\
\hline & & & & U.S.A \\
\hline
\end{tabular}

${ }^{\mathrm{a}}$ Gender of individual samples listed after cultivar name: $\mathrm{F}=$ female, $\mathrm{M}=$ male, $\mathrm{H}=$ hermaphrodite; bunimproved and improved cultivar status from Kim et al. (2002) 
Table 3. Morphological characteristics adapted from International Board of Plant Genetic Resources, 1988.

Morphological

Characteristics
Phenotypic range (IPBGR, 1988)
Vegetative traits:

Leaf petiole color

Leaf shape

Leaf teeth shape

Petiole sinus shape
1 - Pale green; 2 - Normal green; 3 - Dark green; 4 - Green and shades of redpurple; 5 - Red-purple; 6 - Other

See IBPGR (1988)

1 - Straight; 2 - Convex; 3 - Concave; 4 - Other

1 - Open; 2 - Slightly open; 3 - Slightly closed; 4 - Strongly closed; 5 - Other

\section{Reproductive traits:}

Male corolla lobe

color

Male corolla tube

color

Inflorescence stalk

color

Female petal color

Fruit shape

Fruit skin color

Fruit flesh color

Fruit central cavity shape
1 - White; 2 - White yellow (cream); 3 - Yellow; 4 - Deep yellow to orange; 5 Greenish; 6 - Dark green; 7 - Yellow/green and red-purple shades; 8 - Red purplish (pinkish); 9 - Dark red-purple (pink); 10 - Other

1 - White; 2 - White yellow (cream); 3 - Yellow; 4 - Deep yellow to orange; 5 Greenish; 6 - Dark green; 7 - Yellow/green and red-purple shades; 8 - Red purplish (pinkish); 9 - Dark red-purple (pink); 10 - Other

1 - Greenish; 2 - Purplish/pinkish; 3 - Dark red-purple/pink; 4 - Other

1 - White; 2 - White yellow (cream); 3 - Yellow; 4 - Deep yellow to orange; 5 Greenish; 6 - Dark green; 7 - Yellow/green and red-purple shades; 8 - Red purplish (pinkish); 9 - Dark red-purple (pink); 10 - Other

1 - Globular; 2 - Round; 3 - High round; 4 - Elliptic; 5 - Oval; 6 - Oblong; 7 Oblong-ellipsoid; 8 - Oblong-blocky; 9 - Elongate; 10 - Lengthened cylindrical; 11 - Pear shaped (pyriform); 12 - Club; 13 - Blossom end tapered; 14 - Acron (heart shaped); 15 - Reniform; 16 - Turbinate inferior 1 - Yellow; 2 - Deep yellow to orange; 3 - Red/purple; 4 - Yellowish green; 5 Green; 6 - Other

1 - Light yellow; 2 - Bright yellow; 3 - Depp yellow to orange; 4 - Reddish orange; 5 - Scarlet; 6 - Other

1 - Irregular; 2 - Round; 3 - Angular; 4 - Slightly star shaped; 5 - Star shaped; 6 Other 


\begin{tabular}{|c|c|}
\hline $\begin{array}{l}\text { Fruit stalk end } \\
\text { shape }\end{array}$ & 1 - Depressed; 3 - Flattened; 5 - Inflated; 7 - Pointed \\
\hline Seed color & $\begin{array}{l}1 \text { - Generally tan; } 2 \text { - Generally grey-yellow; } 3 \text { - Generally grey; } 4 \text { - Generally } \\
\text { brown black; } 5 \text { - Generally black; } 6 \text { - Variable }\end{array}$ \\
\hline Seed surface luster & 3 - Generally dull; 5 - Generally intermediate; 7 - Generally glossy \\
\hline
\end{tabular}


Table 4. Microsatellite loci with primer design, size of repeat unit, linkage group, fluorophore label, marker ID and combination of primer pairs.

\begin{tabular}{|c|c|c|c|c|c|c|}
\hline Locus & Forward Primer $\left(5^{\prime} \rightarrow 3^{\prime}\right)$ & Reverse Primer $\left(5^{\prime} \rightarrow 3^{\prime}\right)$ & $\begin{array}{l}\text { Size of } \\
\text { Repeat }^{\mathrm{a}}\end{array}$ & $\begin{array}{l}\text { Linkage } \\
\text { Group }\end{array}$ & $\begin{array}{c}\text { Forward } \\
\text { Label }\end{array}$ & $\begin{array}{c}\text { Combo } \\
\text { Pair }^{\mathrm{b}}\end{array}$ \\
\hline CPM1606CC & AAGGAATCAAAAGGTAACTGCTGC & TTCTTCCTCCACTGATCGCC & 2 & 2 & 6FAM & $\mathrm{a}$ \\
\hline $\mathrm{Ctg}-27 \mathrm{CC}$ & TGAGCCTTGAACCCAAAGTTTC & TGCTTCAAAGACAAGAAAGGCTG & 2 & 3 & HEX & $\mathrm{b}$ \\
\hline P3K2696CC & CATTCTTTTTCTCGGGATCCAA & TGATGAATAATTAGGGCAGGAGG & 2 & 4 & NED & $\mathrm{b}$ \\
\hline P3K7483A5 & GCAGCCCGTACAGAAGAGGA & CTCTGAGCAGCAAGCCAACA & 3 & 8 & PET & a \\
\hline CPM1564CC & GGGCCTTTGATCCATGTGAA & CCTATGGGCTCAGTCCACCA & 2 & 8 & 6FAM & $\mathrm{c}$ \\
\hline P3K5796CC & AGGGAGGTGATGGAGCCAAT & CCTTTGAATCCCACCACCAA & 2 & 1 & HEX & $\mathrm{c}$ \\
\hline P6K946CC & GCTGTAATGATTCCTGCACCA & AAACCACAACCAAAATATACGCA & 2 & 2 & NED & $\mathrm{d}$ \\
\hline P6K1213CC & GGATGATTCACACCCCACAT & AAGCCGTCACTAAAGCTAGAAGC & 3 & 9 & PET & $\mathrm{d}$ \\
\hline $\mathrm{P} 3 \mathrm{~K} 855 \mathrm{C} 0$ & TGGATGCATGTGATGTGTTTTG & AAGCCCAAGAGAAATGGGGA & 2 & 1 & 6FAM & $\mathrm{e}$ \\
\hline P3K2981YC0 & GCCATCTGCTTGCAAGGTCT & TCAGGGGATGGTTCAGGAGA & 3 & 1 & HEX & $1 \mathrm{f}$ \\
\hline P3K2974CC & TCAGAATTTCCATGTCCACAGC & TGTTTGTCCTACTGCGTGAAAGTT & 2 & 5 & NED & $\mathrm{e}$ \\
\hline P8K209CC & ATTAGGGATGGGTGTGCCG & AGCCTGGAGCTTACCTTCCG & 3 & 9 & PET & $\mathrm{f}$ \\
\hline CPM1774CC & GGCACTGTGACTGGCATTGA & CTGACAACTGTGACCCCACG & 2 & 9 & 6FAM & $\mathrm{g}$ \\
\hline P3K911CC & TGGAAATCCCCCTCACTCCT & GACATTTATATCTGCGAGCGCC & 2 & 7 & HEX & $\mathrm{h}$ \\
\hline P3K2851CC & TAGAAGCAGATGCGGAGGGA & TCCAGACCCAAAAACCCAAA & 2 & 7 & NED & $\mathrm{g}$ \\
\hline P3K7022CC & ACGAACACTTGCATGAGACCC & CCCCACGAAGCTTGCTACAG & 2 & 5 & PET & $\mathrm{h}$ \\
\hline P3K6947CC & АТтСТТССТСССТСССТССС & AAAAAGGGTGGGGGTTTGAG & 2 & 4 & 6FAM & $\mathrm{i}$ \\
\hline P3K1776CC & TGTTTGCATTTTTGCTTTCCC & AATGATCAATCCCTACGCGTTC & 2 & 2 & HEX & $\mathrm{i}$ \\
\hline $\mathrm{P} 3 \mathrm{~K} 736 \mathrm{CC}$ & СТCTCTTCAAGGCCATCTCCA & GCCATGAAGTTGGCGAAGTATT & 2 & 4 & NED & $\mathrm{j}$ \\
\hline P3K6818S5 & CCGTCACTATATGTATCACCCAGA & TGTGTGATTTTGTATGCGTGTTT & 2 & 5 & PET & $\mathrm{j}$ \\
\hline
\end{tabular}


Table 5. $\chi^{2}$ test for heterogeneity among Panamanian regions for qualitative morphological traits.

\begin{tabular}{|c|c|c|c|}
\hline \multirow[b]{2}{*}{ Morphological Trait } & \multicolumn{3}{|c|}{ Log-likelihood } \\
\hline & $\begin{array}{l}\text { Ratio } \chi^{2} \\
(P \text { value })\end{array}$ & $\begin{array}{l}\text { Pearson } \chi^{2} \\
(P \text { value })\end{array}$ & $n$ \\
\hline \multicolumn{4}{|l|}{ Vegetative traits } \\
\hline Leaf petiole color & $0.04 *$ & 0.16 & 50 \\
\hline Leaf shape & $0.02 *$ & $0.01 *$ & 51 \\
\hline Leaf teeth shape & 0.48 & 0.68 & 51 \\
\hline Petiole sinus shape & 0.39 & 0.47 & 51 \\
\hline \multicolumn{4}{|l|}{ Reproductive traits } \\
\hline Male corolla lobe color & 0.08 & 0.16 & 13 \\
\hline Male corolla tube color & 0.44 & 0.54 & 14 \\
\hline Inflorescence stalk color & 0.58 & 0.48 & 40 \\
\hline Female petal color & 0.66 & 0.75 & 17 \\
\hline Fruit shape & 0.68 & 0.78 & 11 \\
\hline Fruit skin color & 0.09 & 0.17 & 11 \\
\hline Fruit flesh color & $0.04 *$ & $0.01 *$ & 9 \\
\hline Fruit central cavity shape & $0.01 *$ & $0.02 *$ & 8 \\
\hline Fruit stalk end shape & 0.41 & 0.47 & 10 \\
\hline Seed color & 0.07 & $0.01 *$ & 11 \\
\hline Seed surface luster & 0.12 & 0.13 & 9 \\
\hline
\end{tabular}

$* P<0.05$ 
Table 6. Mean measurements for papaya vegetative and reproductive quantitative traits within Panamanian regions.

\begin{tabular}{cccccc}
\hline & Mean length of & Mean length & Mean width & Mean fruit \\
diameter & $\begin{array}{c}\text { Mean of length } \\
\text { of fruit }\end{array}$ & $\begin{array}{c}\text { of leaf }(\mathrm{cm}) \\
\text { of leaf }(\mathrm{cm})\end{array}$ & $\begin{array}{c}(\mathrm{cm}) \\
\text { pegion }(\mathrm{cm})\end{array}$ & $\begin{array}{cccc}* \\
\text { petiole }(\mathrm{cm})\end{array}$ \\
\hline Canal & $87.5 \pm 4.9 \mathrm{~A}$ & $47.0 \pm 2.5 \mathrm{~A}$ & $68.4 \pm 3.4 \mathrm{~A}$ & $5.9 \pm 0.6 \mathrm{~A}$ & $2.5 \pm$ n.d. A \\
Northeast & $79.7 \pm 6.9 \mathrm{AB}$ & $39.5 \pm 2.3 \mathrm{~A}$ & $62.2 \pm 3.2 \mathrm{~A}$ & n.d. & n.d. \\
South & $61.3 \pm 7.9 \mathrm{~B}$ & $38.8 \pm 3.9 \mathrm{~A}$ & $58.1 \pm 6.6 \mathrm{~A}$ & $8.1 \mathrm{~A}$ & $4.6 \mathrm{~A}$ \\
West & $97.3 \pm 7.5 \mathrm{~A}$ & $51.0 \pm 3.8 \mathrm{~A}$ & $77.0 \pm 6.3 \mathrm{~A}$ & $3.9 \pm 0.2 \mathrm{~A}$ & $2.6 \pm 0.7 \mathrm{~A}$ \\
\hline
\end{tabular}

$* P<0.05$ (one-way ANOVA); letters indicate Tukey significance levels. 
Table 7. Mean measurements for fruit diameter and peduncle length in Panamá and Costa Rica regions.

\begin{tabular}{ccc}
\hline Region & $\begin{array}{c}\text { Mean fruit } \\
\text { diameter }(\mathrm{cm})^{* * *}\end{array}$ & $\begin{array}{c}\text { Mean length of } \\
\text { fruit peduncle }(\mathrm{cm})\end{array}$ \\
\hline Panamá & $5.7 \pm 0.6 \mathrm{BC}$ & $3.0 \pm 0.5 \mathrm{~A}$ \\
Caribbean $\left(\mathrm{CR}^{\mathrm{a}}\right)$ & $7.5 \pm 0.3 \mathrm{AB}$ & $3.0 \pm 0.3 \mathrm{~A}$ \\
Northwest Pacific (CR) & $6.6 \pm 0.4 \mathrm{BC}$ & $3.0 \pm 0.2 \mathrm{~A}$ \\
Nicoya (CR) & $5.2 \pm 0.2 \mathrm{C}$ & $3.2 \pm 0.6 \mathrm{~A}$ \\
Central Pacific (CR) & $7.6 \pm 0.7 \mathrm{AB}$ & $4.4 \pm 0.5 \mathrm{~A}$ \\
Southwest Pacific (CR) & $9.0 \pm 0.8 \mathrm{~A}$ & $4.0 \pm 0.9 \mathrm{~A}$ \\
\hline
\end{tabular}

${ }^{\mathrm{a}} \mathrm{CR}=$ Costa Rica; $* * * P<0.0001$ (one-way ANOVA); letters indicate Tukey significance levels. 
Table 8. Allelic diversity and deviation from Hardy-Weinberg Equilibrium of papaya in four Panamanian regional populations.

\begin{tabular}{|c|c|c|c|c|c|c|c|c|c|c|c|c|c|}
\hline $\begin{array}{l}\text { Regional } \\
\text { Population }\end{array}$ & & 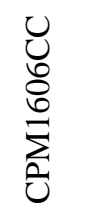 & 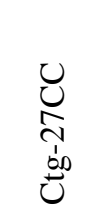 & 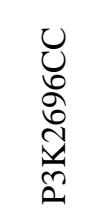 & 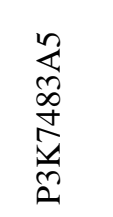 & \begin{tabular}{l} 
U \\
\multirow{Q}{0}{} \\
$\stackrel{n}{n}$ \\
$\sum_{0}$
\end{tabular} & $\begin{array}{l}\text { 己ू. } \\
\curvearrowright \\
\hat{2} \\
\frac{2}{n}\end{array}$ & 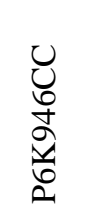 & 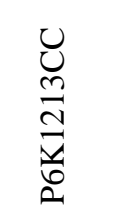 & $\begin{array}{l}8 \\
\mathscr{n} \\
\infty \\
y \\
\tilde{n}\end{array}$ & 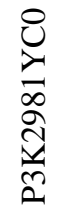 & 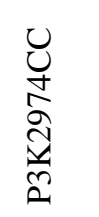 & $\begin{array}{l}\text { U } \\
8 \\
\stackrel{\overbrace{}}{0} \\
\infty \\
\infty \\
0\end{array}$ \\
\hline Northeast & $A^{\mathrm{b}}$ & 3 & 5 & 3 & 6 & 3 & 1 & 1 & 4 & 5 & 4 & 2 & 5 \\
\hline \multirow[t]{2}{*}{$(N=10)$} & $H_{E}^{\mathrm{c}}$ & 0.47 & 0.75 & 0.57 & 0.58 & 0.65 & $0.00^{\mathrm{f}}$ & $0.00^{\mathrm{f}}$ & 0.64 & 0.78 & 0.69 & 0.52 & 0.72 \\
\hline & $H_{O}{ }^{\mathrm{d}}$ & 0.40 & 0.90 & 1.00 & $0.20 *$ & 0.70 & $0.00^{\mathrm{f}}$ & $0.00^{\mathrm{f}}$ & 0.40 & 1.00 & 0.90 & 0.90 & 0.90 \\
\hline \multirow{3}{*}{$\begin{array}{l}\text { Canal } \\
\qquad(N=49)\end{array}$} & $A$ & 7 & 12 & 4 & 9 & 9 & 7 & 4 & 8 & 13 & 5 & 4 & 9 \\
\hline & $H_{E}$ & 0.71 & 0.86 & 0.69 & 0.82 & 0.72 & 0.30 & 0.10 & 0.71 & 0.87 & 0.63 & 0.47 & 0.67 \\
\hline & $H_{O}$ & 0.61 & $0.76^{*}$ & $0.47^{* * *}$ & 0.71 & 0.61 & 0.24 & $0.02^{* *}$ & 0.63 & 0.78 & 0.63 & 0.47 & 0.59 \\
\hline \multirow{3}{*}{$\begin{array}{l}\text { South } \\
\qquad(N=13)\end{array}$} & $A$ & 4 & 11 & 6 & 9 & 5 & 3 & 3 & 4 & 11 & 6 & 5 & 5 \\
\hline & $H_{E}$ & 0.66 & 0.86 & 0.68 & 0.78 & 0.80 & 0.39 & 0.28 & 0.66 & 0.86 & 0.79 & 0.72 & 0.66 \\
\hline & $H_{O}$ & 0.46 & $0.38^{* * *}$ & 0.38 & 0.69 & 0.77 & 0.46 & 0.15 & 0.46 & 0.85 & 0.62 & 0.46 & 0.85 \\
\hline \multirow{3}{*}{$\begin{array}{l}\text { West } \\
\qquad(N=10)\end{array}$} & $A$ & 3 & 12 & 5 & 8 & 5 & 2 & 3 & 4 & 8 & 5 & 3 & 7 \\
\hline & $H_{E}$ & 0.28 & 0.94 & 0.57 & 0.88 & 0.72 & 0.51 & 0.19 & 0.66 & 0.90 & 0.74 & 0.19 & 0.80 \\
\hline & $H_{O}$ & 0.10 & 0.80 & 0.40 & 0.80 & 0.50 & 0.20 & 0.20 & 0.70 & 0.80 & 0.40 & 0.20 & 0.90 \\
\hline \multirow{3}{*}{$\begin{array}{l}\text { Cultivars } \\
\qquad(N=14)\end{array}$} & A & 4 & 9 & 5 & 6 & 5 & 4 & 3 & 5 & 10 & 4 & 4 & 7 \\
\hline & $H_{E}$ & 0.47 & 0.71 & 0.74 & 0.75 & 0.75 & 0.66 & 0.58 & 0.78 & 0.87 & 0.60 & 0.73 & 0.63 \\
\hline & $H_{O}$ & 0.21 & $0.21^{* * *}$ & $0.29^{* *}$ & $0.21^{* * *}$ & $0.29^{* *}$ & $0.07^{* * * *}$ & 0.14 & $0.14^{* * *}$ & 0.50 & 0.29 & $0.29^{*}$ & $0.14^{* * * *}$ \\
\hline $\begin{array}{l}\text { All } \\
\qquad(N=96)\end{array}$ & $A$ & 7 & 21 & 6 & 11 & 9 & 6 & 5 & 7 & 15 & 6 & 5 & 10 \\
\hline
\end{tabular}


Table 8 (cont.)

\begin{tabular}{|c|c|c|c|c|c|c|c|c|c|c|c|c|}
\hline $\begin{array}{l}\text { Regional } \\
\text { Population }\end{array}$ & & 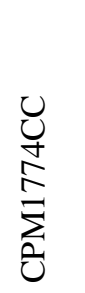 & $\begin{array}{l}u \\
\tilde{\sigma} \\
\frac{\tilde{\sigma}}{2} \\
\tilde{\Omega}\end{array}$ & $\begin{array}{l}u \\
\tilde{\sim} \\
\infty \\
\tilde{N} \\
\tilde{n} \\
\tilde{n}\end{array}$ & 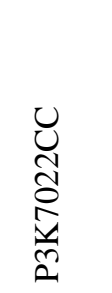 & 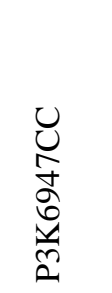 & 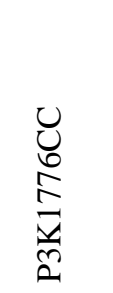 & $\begin{array}{l}\text { U } \\
\stackrel{0}{0} \\
\frac{n}{2} \\
\tilde{n}\end{array}$ & $\begin{array}{l}n \\
\tilde{\infty} \\
\infty \\
\infty \\
0 \\
⿱ ⺌ \\
\tilde{n}\end{array}$ & $\begin{array}{c}\text { Mean } \\
\text { all } \\
\text { loci }\end{array}$ & $\begin{array}{c}\text { Percent } \\
\text { sign. } \\
\text { deviation } \\
\text { from } \\
\text { HWE }\end{array}$ & $F^{\mathrm{a}}$ \\
\hline \multirow{3}{*}{$\begin{array}{l}\text { Northeast } \\
\qquad(N=10)\end{array}$} & $A$ & 4 & 3 & 3 & 3 & 3 & 7 & 3 & 2 & 3.8 & & \\
\hline & $H_{E}$ & 0.54 & 0.64 & 0.62 & 0.56 & 0.62 & 0.82 & 0.42 & 0.51 & 0.62 & & \\
\hline & $H_{O}$ & 0.70 & 1.00 & 0.40 & 0.40 & $0.90 *$ & 1.00 & 0.10 & 0.80 & 0.70 & $10 \%$ & -0.26 \\
\hline \multirow{3}{*}{$\begin{array}{l}\text { Canal } \\
\qquad(N=49)\end{array}$} & $A$ & 3 & 5 & 5 & 5 & 4 & 11 & 6 & 4 & 6.7 & & \\
\hline & $H_{E}$ & 0.52 & 0.54 & 0.74 & 0.71 & 0.54 & 0.78 & 0.63 & 0.48 & 0.62 & & \\
\hline & $H_{O}$ & 0.47 & 0.55 & $0.33^{* * *}$ & 0.47 & $0.98^{* * * *}$ & $0.51^{* * * *}$ & $0.10^{* * * *}$ & 0.45 & 0.52 & $35 \%$ & 0.17 \\
\hline \multirow{3}{*}{$\begin{array}{l}\text { South } \\
\qquad(N=13)\end{array}$} & $A$ & 3 & 5 & 4 & 5 & 3 & 6 & 4 & 2 & 5.2 & & \\
\hline & $H_{E}$ & 0.38 & 0.74 & 0.62 & 0.78 & 0.59 & 0.74 & 0.60 & 0.51 & 0.66 & & \\
\hline & $H_{O}$ & 0.31 & 0.62 & 0.31 & 0.92 & $0.92^{* * *}$ & 0.54 & $0.15^{* *}$ & 0.23 & 0.53 & $15 \%$ & 0.20 \\
\hline \multirow{3}{*}{$\begin{array}{l}\text { West } \\
\qquad(N=10)\end{array}$} & $A$ & 4 & 4 & 4 & 6 & 2 & 2 & 2 & 2 & 4.6 & & \\
\hline & $H_{E}$ & 0.63 & 0.67 & 0.59 & 0.78 & 0.53 & 0.19 & 0.19 & 0.27 & 0.56 & & \\
\hline & $H_{O}$ & 0.60 & 0.20 & 0.40 & 0.90 & 1.00 & 0.00 & 0.00 & 0.10 & 0.46 & $0 \%$ & 0.18 \\
\hline \multirow{3}{*}{$\begin{array}{l}\text { Cultivars } \\
\qquad(N=14)\end{array}$} & $A$ & 3 & 6 & 4 & 7 & 4 & 5 & 5 & 3 & 5.2 & & \\
\hline & $H_{E}$ & 0.56 & 0.78 & 0.48 & 0.85 & 0.71 & 0.66 & 0.76 & 0.61 & 0.68 & & \\
\hline & $H_{O}$ & 0.29 & 0.36 & $0.00^{* * * *}$ & $0.21^{\text {**** }}$ & $0.71^{* * *}$ & $0.14^{* * *}$ & $0.14^{* * *}$ & 0.21 & 0.24 & $65 \%$ & 0.64 \\
\hline All & $A$ & 4 & 6 & 5 & 6 & 4 & 10 & 6 & 3 & 7.6 & & \\
\hline
\end{tabular}

$(N=96)$

${ }^{\mathrm{a}} F=\left(H_{E}-H_{O}\right) / H_{E} ;{ }^{\mathrm{b}} A=$ Number of observed alleles; ${ }^{\mathrm{c}} H_{E}=$ Expected heterozygosity; ${ }^{\mathrm{d}} H_{O}=$ Observed heterozygosity; ${ }^{\mathrm{f}}$ monomorphic loci; *Bonferroni $P<0.0025$; **Bonferroni $P<0.0005$; ***Bonferroni $P<0.00005$ 
Table 9. AMOVA of wild papaya from four Panamanian regional populations.

\begin{tabular}{lccccc}
\multicolumn{1}{c}{ Source of variation } & $\begin{array}{c}\text { Degrees of } \\
\text { freedom }\end{array}$ & $\begin{array}{c}\text { Sum of } \\
\text { squares }\end{array}$ & $\begin{array}{c}\text { Variance } \\
\text { components }\end{array}$ & $\begin{array}{c}\text { Percentage } \\
\text { of variation }\end{array}$ & $F_{\text {-statistics }}$ \\
\hline Among populations & 3 & 63.285 & 0.43711 & $6.63 \%$ & $\mathrm{~F}_{\mathrm{ST}}=0.06630$ \\
$\begin{array}{l}\text { Among individuals within } \\
\quad 78\end{array}$ & 549.386 & 0.88756 & $13.46 \%$ & $\mathrm{~F}_{\mathrm{IS}}=0.14418$ \\
$\quad$ populations & 82 & 432.000 & 5.26829 & $79.91 \%$ & $\mathrm{~F}_{\mathrm{IT}}=0.20092$ \\
Within individuals & 163 & 1044.671 & 6.59296 & & \\
Total & & & & \\
\hline
\end{tabular}


Table 10. STRUCTURE cluster percentages for cultivar individuals and individuals in the four Panamanian regional populations.

\begin{tabular}{lllll}
\hline \multicolumn{1}{c}{ Sample ID } & $\begin{array}{l}\text { Cluster 1 } \\
\text { (Purple) }\end{array}$ & $\begin{array}{l}\text { Cluster 2 } \\
\text { (Light Blue) }\end{array}$ & $\begin{array}{l}\text { Cluster 3 } \\
\text { (Green) }\end{array}$ & $\begin{array}{l}\text { Cluster 4 } \\
\text { (Yellow) }\end{array}$ \\
\hline Cultivars & & & & \\
928M & 0.041 & 0.81 & 0.141 & 0.008 \\
H11F & 0.002 & 0.003 & 0.003 & 0.993 \\
H16_F & 0.002 & 0.007 & 0.005 & 0.986 \\
HCAR14 & 0.009 & 0.021 & 0.77 & 0.2 \\
Sunup & 0.001 & 0.002 & 0.002 & 0.995 \\
H302_F & 0.001 & 0.003 & 0.003 & 0.993 \\
CO_H & 0.029 & 0.743 & 0.015 & 0.213 \\
H196 & 0.006 & 0.007 & 0.003 & 0.984 \\
918H & 0.002 & 0.015 & 0.007 & 0.976 \\
HCAR_207 & 0.002 & 0.096 & 0.012 & 0.89 \\
No31 & 0.004 & 0.358 & 0.006 & 0.632 \\
DREW & 0.002 & 0.95 & 0.02 & 0.027 \\
Kaek Dum & 0.01 & 0.263 & 0.013 & 0.714 \\
H164 & 0.004 & 0.009 & 0.005 & 0.982
\end{tabular}

\section{Northeastern region}

$\begin{array}{lllll}\text { Pa25 } & 0.004 & 0.009 & 0.984 & 0.004 \\ \text { Pa26 } & 0.003 & 0.004 & 0.99 & 0.002 \\ \text { Pa27 } & 0.002 & 0.006 & 0.988 & 0.003 \\ \text { Pa28 } & 0.005 & 0.004 & 0.987 & 0.003 \\ \text { Pa29 } & 0.002 & 0.007 & 0.988 & 0.004 \\ \text { Pa30 } & 0.002 & 0.004 & 0.992 & 0.002 \\ \text { Pa31 } & 0.003 & 0.004 & 0.991 & 0.002 \\ \text { Pa32 } & 0.007 & 0.952 & 0.035 & 0.006 \\ \text { Pa33 } & 0.004 & 0.946 & 0.044 & 0.005\end{array}$




\begin{tabular}{|c|c|c|c|c|}
\hline Pa58 & 0.014 & 0.97 & 0.011 & 0.004 \\
\hline Pa15 & 0.936 & 0.037 & 0.02 & 0.006 \\
\hline $\mathrm{Pa} 16$ & 0.994 & 0.002 & 0.002 & 0.002 \\
\hline $\mathrm{Pa} 17$ & 0.145 & 0.827 & 0.026 & 0.002 \\
\hline Pa18 & 0.006 & 0.98 & 0.007 & 0.008 \\
\hline Pa19 & 0.005 & 0.939 & 0.051 & 0.006 \\
\hline $\mathrm{Pa} 20$ & 0.007 & 0.963 & 0.027 & 0.004 \\
\hline $\mathrm{Pa} 21$ & 0.012 & 0.966 & 0.017 & 0.005 \\
\hline $\mathrm{Pa} 22$ & 0.994 & 0.002 & 0.002 & 0.002 \\
\hline $\mathrm{Pa} 23$ & 0.871 & 0.107 & 0.016 & 0.006 \\
\hline $\mathrm{Pa} 24$ & 0.005 & 0.972 & 0.014 & 0.009 \\
\hline $\mathrm{Pa} 34$ & 0.008 & 0.981 & 0.007 & 0.004 \\
\hline $\mathrm{Pa} 35$ & 0.006 & 0.98 & 0.011 & 0.003 \\
\hline Pa36 & 0.012 & 0.803 & 0.164 & 0.022 \\
\hline $\mathrm{Pa} 37$ & 0.007 & 0.948 & 0.04 & 0.005 \\
\hline Pa38 & 0.005 & 0.967 & 0.017 & 0.011 \\
\hline Pa39 & 0.007 & 0.97 & 0.02 & 0.003 \\
\hline $\mathrm{Pa} 40$ & 0.047 & 0.777 & 0.171 & 0.005 \\
\hline $\mathrm{Pa} 41$ & 0.008 & 0.968 & 0.018 & 0.005 \\
\hline $\mathrm{Pa} 42$ & 0.001 & 0.002 & 0.002 & 0.995 \\
\hline $\mathrm{Pa} 43$ & 0.013 & 0.706 & 0.279 & 0.002 \\
\hline $\mathrm{Pa} 44$ & 0.046 & 0.387 & 0.561 & 0.007 \\
\hline $\mathrm{Pa} 45$ & 0.022 & 0.025 & 0.95 & 0.003 \\
\hline $\mathrm{Pa} 46$ & 0.011 & 0.003 & 0.985 & 0.002 \\
\hline $\mathrm{Pa} 47$ & 0.045 & 0.015 & 0.937 & 0.003 \\
\hline $\mathrm{Pa} 48$ & 0.005 & 0.035 & 0.957 & 0.003 \\
\hline $\mathrm{Pa} 49$ & 0.003 & 0.004 & 0.991 & 0.002 \\
\hline $\mathrm{Pa} 50$ & 0.004 & 0.003 & 0.991 & 0.002 \\
\hline Pa51 & 0.005 & 0.003 & 0.99 & 0.002 \\
\hline Pa52 & 0.064 & 0.156 & 0.771 & 0.01 \\
\hline
\end{tabular}




\begin{tabular}{|c|c|c|c|c|}
\hline Pa53 & 0.007 & 0.014 & 0.976 & 0.003 \\
\hline $\mathrm{Pa} 54$ & 0.002 & 0.744 & 0.186 & 0.068 \\
\hline Pa56 & 0.993 & 0.003 & 0.002 & 0.002 \\
\hline $\mathrm{Pa} 57$ & 0.99 & 0.005 & 0.003 & 0.002 \\
\hline $\mathrm{Pa} 59$ & 0.004 & 0.005 & 0.988 & 0.003 \\
\hline Pa60 & 0.004 & 0.969 & 0.022 & 0.005 \\
\hline Pa61 & 0.009 & 0.948 & 0.038 & 0.005 \\
\hline Pa62 & 0.01 & 0.95 & 0.028 & 0.013 \\
\hline $\mathrm{Pa} 63$ & 0.005 & 0.908 & 0.08 & 0.007 \\
\hline Pa64 & 0.006 & 0.804 & 0.176 & 0.014 \\
\hline $\mathrm{Pa} 65$ & 0.014 & 0.961 & 0.021 & 0.003 \\
\hline Pa66 & 0.079 & 0.018 & 0.9 & 0.002 \\
\hline $\mathrm{Pa} 67$ & 0.011 & 0.98 & 0.004 & 0.005 \\
\hline $\mathrm{Pa} 76$ & 0.002 & 0.003 & 0.993 & 0.002 \\
\hline $\mathrm{Pa} 77$ & 0.004 & 0.003 & 0.991 & 0.002 \\
\hline $\mathrm{Pa} 78$ & 0.003 & 0.003 & 0.992 & 0.002 \\
\hline $\mathrm{Pa} 79$ & 0.022 & 0.302 & 0.651 & 0.025 \\
\hline $\mathrm{Pa} 80$ & 0.018 & 0.965 & 0.014 & 0.003 \\
\hline Pa81 & 0.995 & 0.002 & 0.002 & 0.001 \\
\hline $\mathrm{Pa} 82$ & 0.993 & 0.003 & 0.003 & 0.001 \\
\hline
\end{tabular}

Southern region

$\begin{array}{lllll}\text { Pa1 } & 0.185 & 0.667 & 0.145 & 0.003 \\ \mathrm{~Pa} 2 & 0.009 & 0.671 & 0.315 & 0.005 \\ \mathrm{~Pa} 4 & 0.003 & 0.927 & 0.01 & 0.059 \\ \mathrm{~Pa} 11 & 0.011 & 0.012 & 0.973 \\ \mathrm{~Pa} 12 & 0.004 & 0.986 & 0.005 & 0.003 \\ \mathrm{~Pa} 13 & 0.006 & 0.981 & 0.011 & 0.004 \\ \mathrm{~Pa} 14 & 0.004 & 0.232 & 0.063 & 0.687 \\ \mathrm{~Pa} 70 & 0.018 & 0.957 & 0.038 & 0.003 \\ \mathrm{~Pa} 71 & 0.002 & 0.948 & 0.018 & 0.025\end{array}$




$\begin{array}{lllll}\text { Pa72 } & 0.005 & 0.98 & 0.011 & 0.004 \\ \text { Pa73 } & 0.003 & 0.989 & 0.004 & 0.004 \\ \text { Pa74 } & 0.002 & 0.976 & 0.009 & 0.012 \\ \text { Pa75 } & 0.004 & 0.987 & 0.005 & 0.005\end{array}$

Western region

$\begin{array}{lllll}\text { Pa5 } & 0.002 & 0.191 & 0.78 & 0.027 \\ \text { Pa6 } & 0.041 & 0.943 & 0.007 & 0.008 \\ \text { Pa7 } & 0.036 & 0.957 & 0.004 & 0.003 \\ \text { Pa8_1 } & 0.017 & 0.978 & 0.003 & 0.003 \\ \text { Pa8_2 } & 0.04 & 0.948 & 0.009 & 0.002 \\ \text { Pa9 } & 0.008 & 0.986 & 0.004 & 0.002 \\ \text { Pa10 } & 0.067 & 0.919 & 0.008 & 0.005 \\ \text { Pa55 } & 0.012 & 0.982 & 0.003 & 0.002 \\ \text { Pa68 } & 0.007 & 0.987 & 0.004 & 0.002\end{array}$


Table 11. Demographic indices for Panamanian regional populations and cultivars.

\begin{tabular}{cccccc}
\hline Region & $M^{\mathrm{a}}$ & $\ln \beta_{1}{ }^{\mathrm{b}}$ & $\ln \beta_{2}{ }^{\mathrm{c}}$ & $k^{\mathrm{d}}(P)$ & $g^{\mathrm{e}}$ \\
\hline Northeast & 0.527 & 2.215 & 1.178 & 0.84 & 5.66 \\
Canal & 0.607 & 1.760 & 1.119 & 0.36 & 5.35 \\
South & 0.578 & 1.545 & 0.974 & 0.70 & 4.06 \\
West & 0.685 & 0.592 & 0.463 & 0.04 & 7.82 \\
All natural individuals & 0.599 & 1.547 & 1.071 & 0.53 & 5.22 \\
Cultivars & 0.549 & 1.509 & 1.291 & 0.99 & 1.76 \\
\hline
\end{tabular}

${ }^{\mathrm{a}} M=$ Garza-Williamson index; ${ }^{\mathrm{b}} \ln \beta_{1}=$ natural $\log$ ratio of the mean $\beta$ index estimate; ${ }^{\mathrm{c}} \ln \beta_{2}$, mean of the natural $\log$ ratios $\beta$ index estimate; ${ }^{\mathrm{d}} k=$ within-locus variability statistic ( $P$-value reported); ${ }^{\mathrm{e}} g=$ between - locus variability statistic 


\section{FIGURE LEGENDS}

Figure 1. Map of all natural individuals collected throughout Panamá. Red triangles represent individuals from Canal region. Purple circles represent individuals from Northeastern region. Blue squares represent individuals from Southern region. Pink hexagons represent individuals from the Western region.

Figure 2. Distribution of vegetative morphological traits among Panamá regional populations. A) Leaf petiole color; B) Leaf teeth shape; C) Petiole sinus shape; D) Leaf shape. For D, leaf shape identification numbers are listed on the $\mathrm{X}$-axis.

Figure 3. Distribution of floral morphological traits. A) Color of male corolla lobes; B) Color of male corolla tube color; C) Color of inflorescence stalk; D) Color of female petals.

Figure 4. Distribution of fruit and seed characteristics. A) Fruit shape; B) Fruit skin color; C) Fruit flesh color; D) Fruit shape of central cavity; E) Shape of stalk end of fruit; F) Seed color.

Figure 5. Pairwise $\mathrm{F}_{\mathrm{ST}}$ values and genetic differentiation between $\mathrm{A}$ ) natural regions in Panamá and B) natural regions and cultivars. Pairwise F $_{S T}$ values are indicated next to lines connecting populations and/or populations and cultivars. Higher $\mathrm{F}_{\mathrm{ST}}$ values have lines of thicker width.

Figure 6. Principal Coordinate of Analysis (PCoA) of the distance matrix of natural individuals and cultivars. Coordinate 1 has $13.1 \%$ of the total variance, and Coordinate 2 has $7.6 \%$ of the total variance. Red horizontal lines represent Cultivars; Green squares represent Northeastern individuals; Blue triangles represent Canal individuals; Yellow circles represent Southern individuals; Pink diamonds represent Western regions.

Figure 7. Map of Panamá with STRUCTURE clusters; each vertical line illustrates an individual and the likelihood it is assigned to one of four genetic clusters determined by Evanno et al. (2005) method. Purple represents Cluster 1; Light blue represents Cluster 2; Green represents Cluster 3; Yellow represents Cluster 4. 
Figure 1

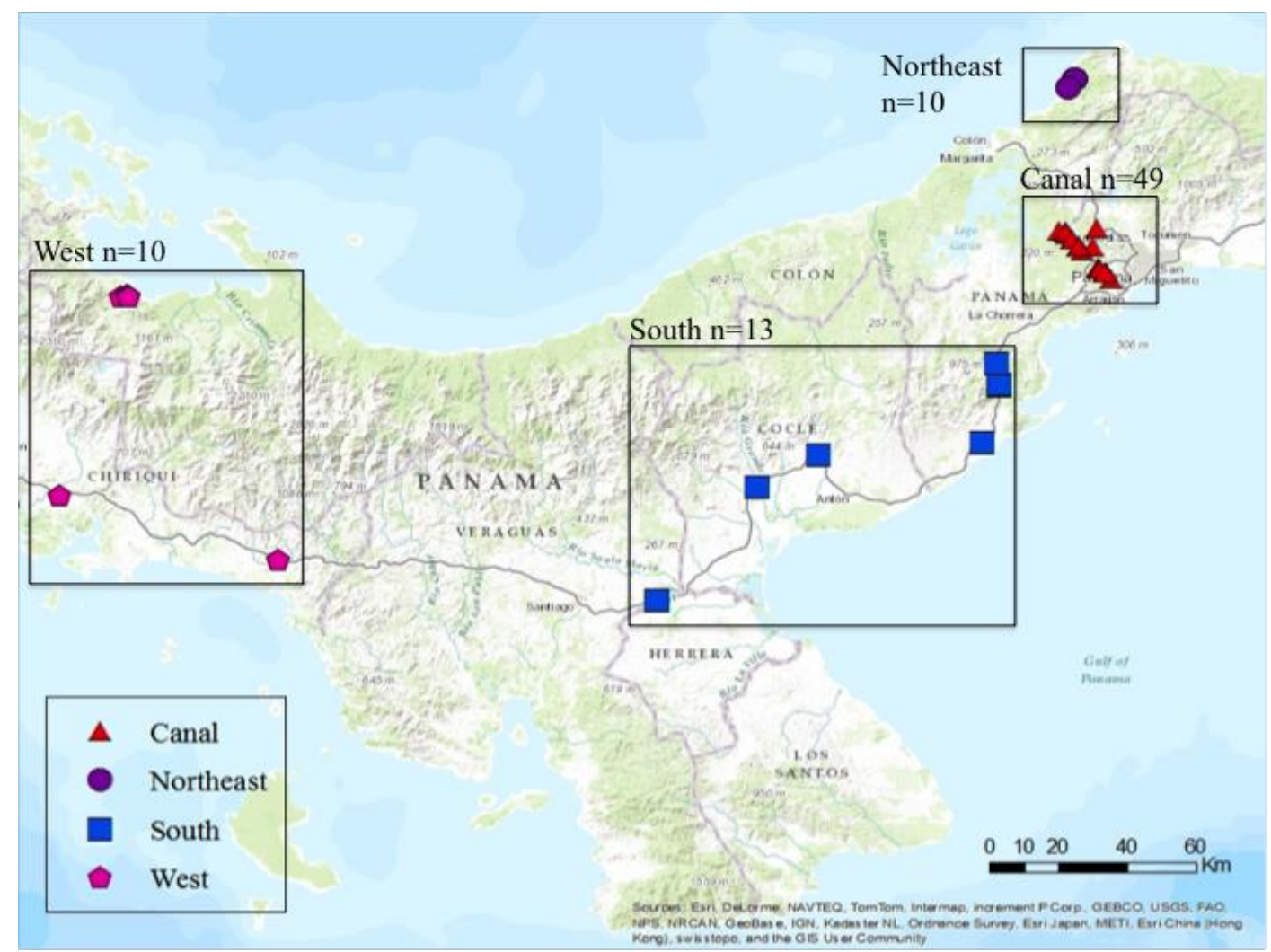


Figure 2
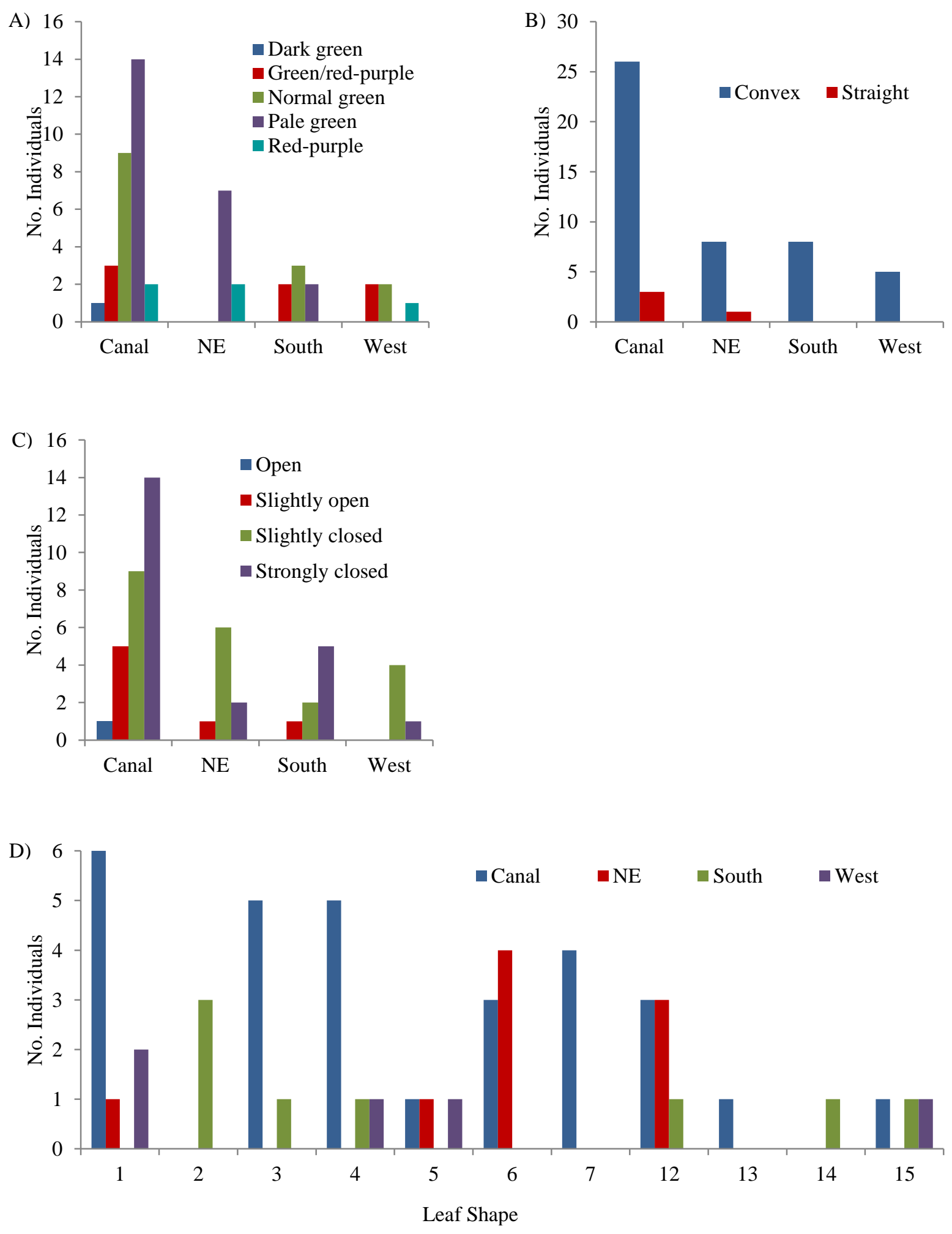
Figure 3
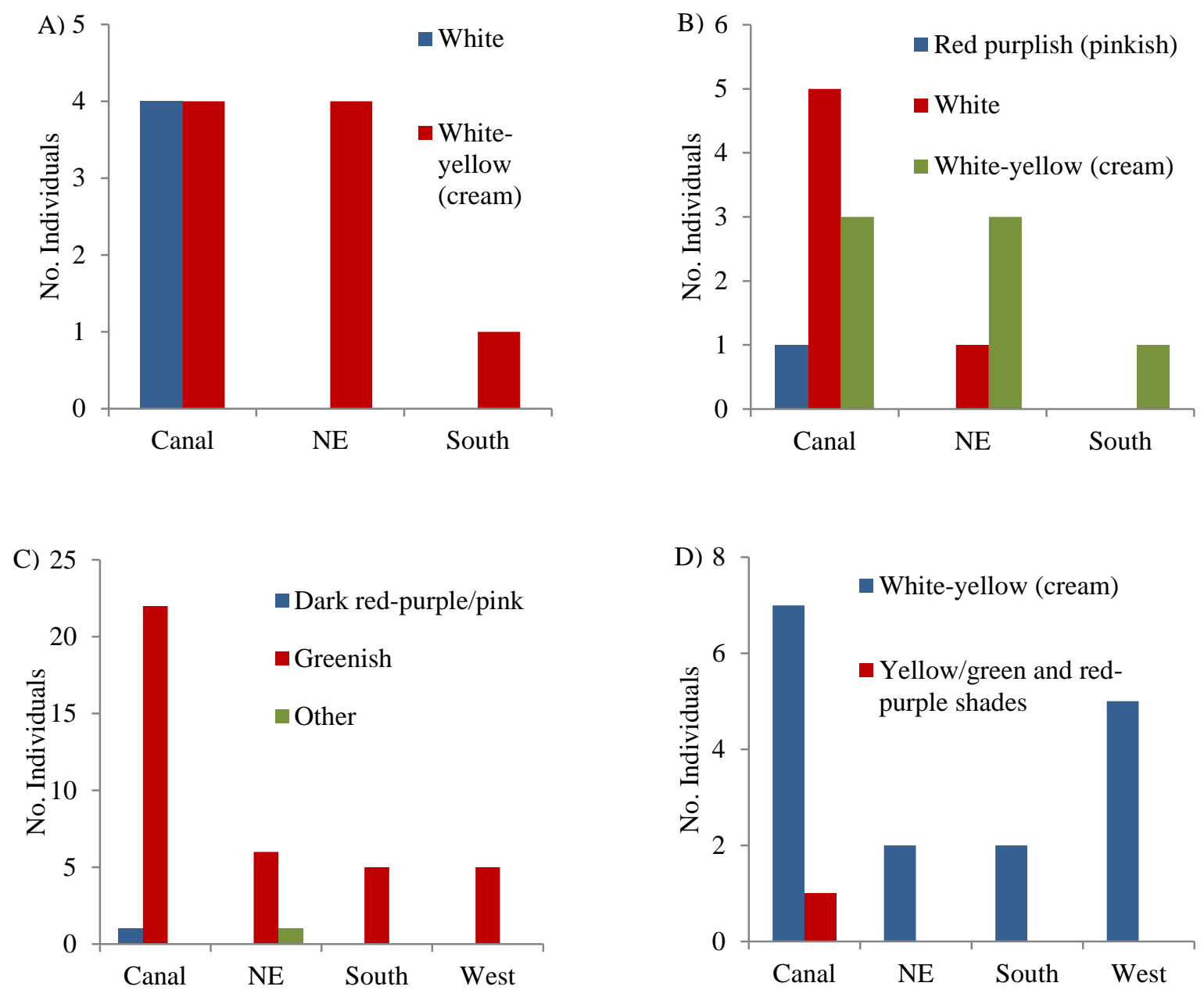


\section{Figure 4}
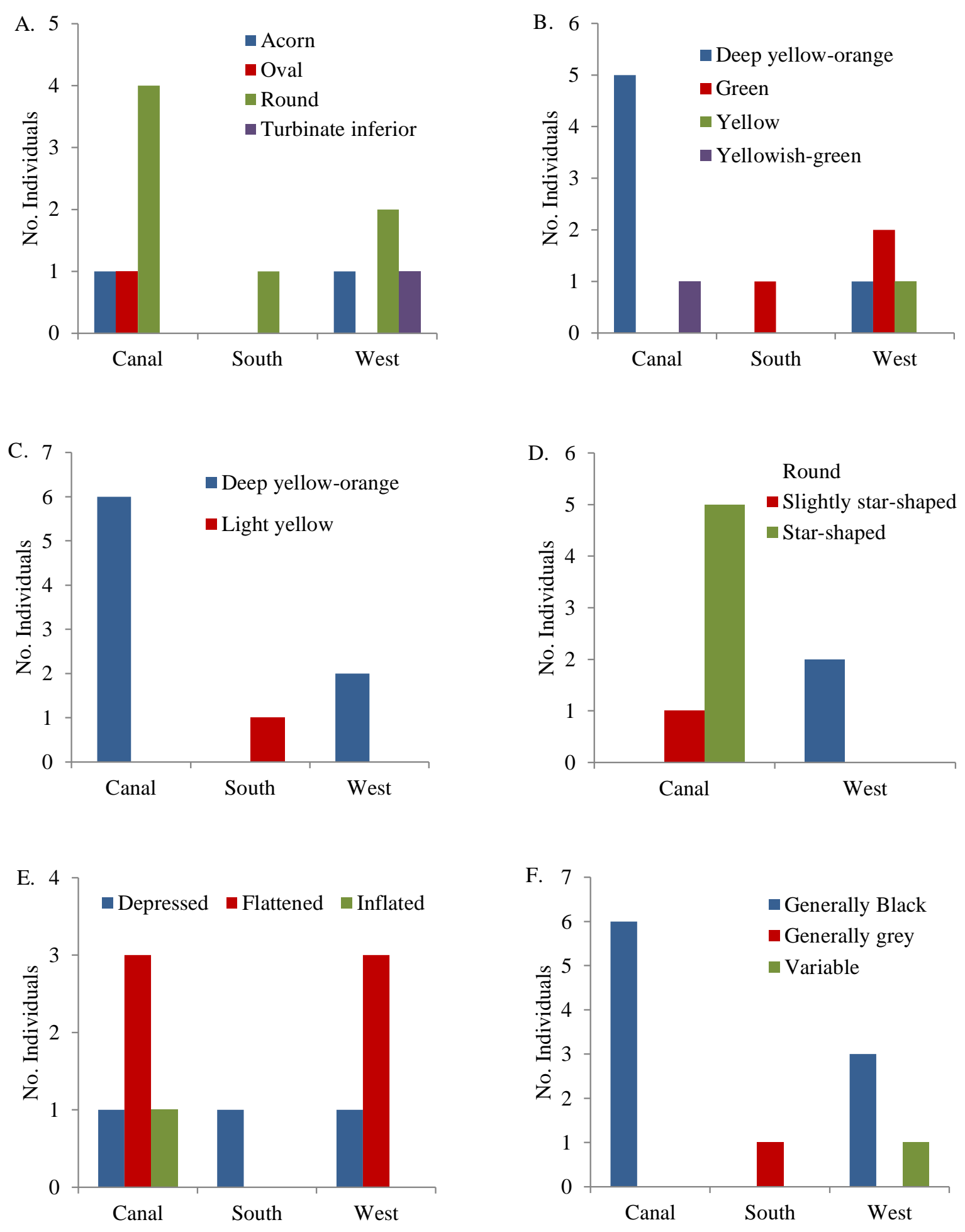


\section{Figure 5}

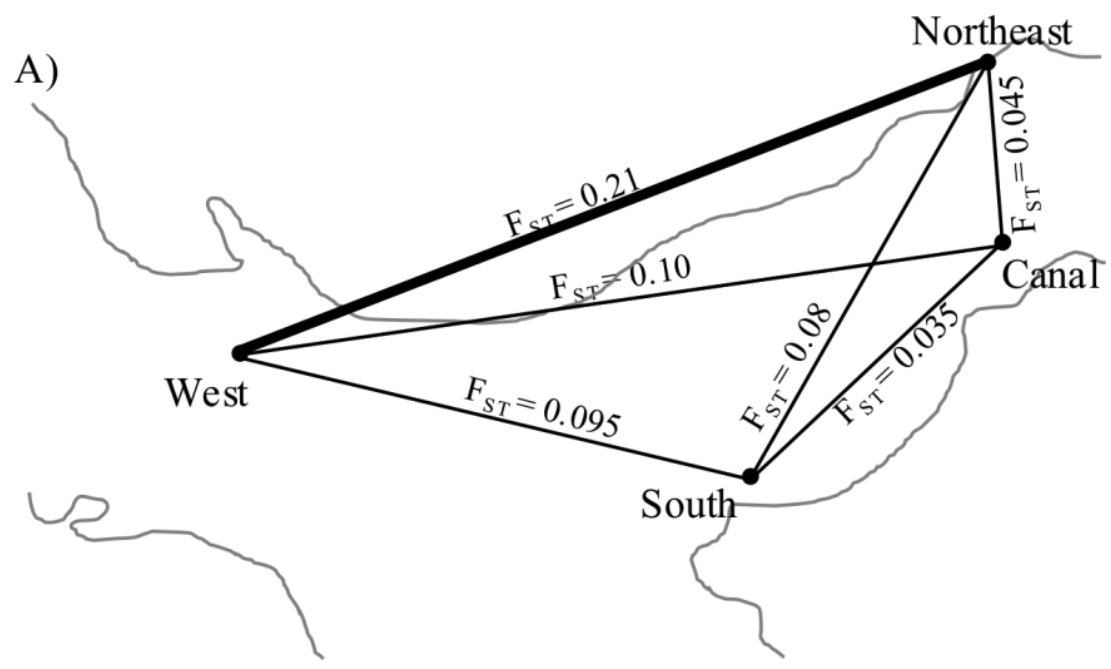

B)

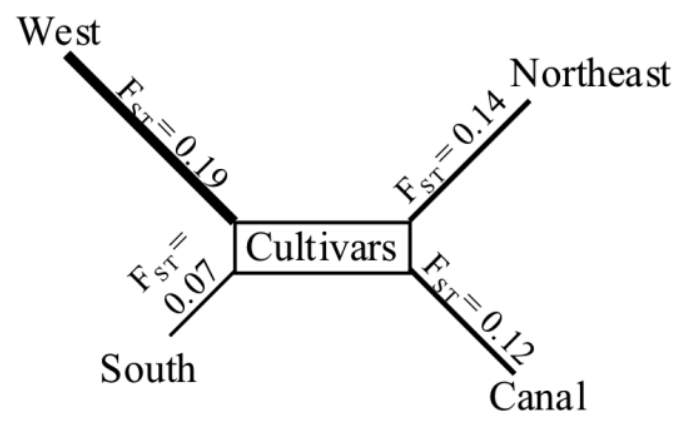


Figure 6

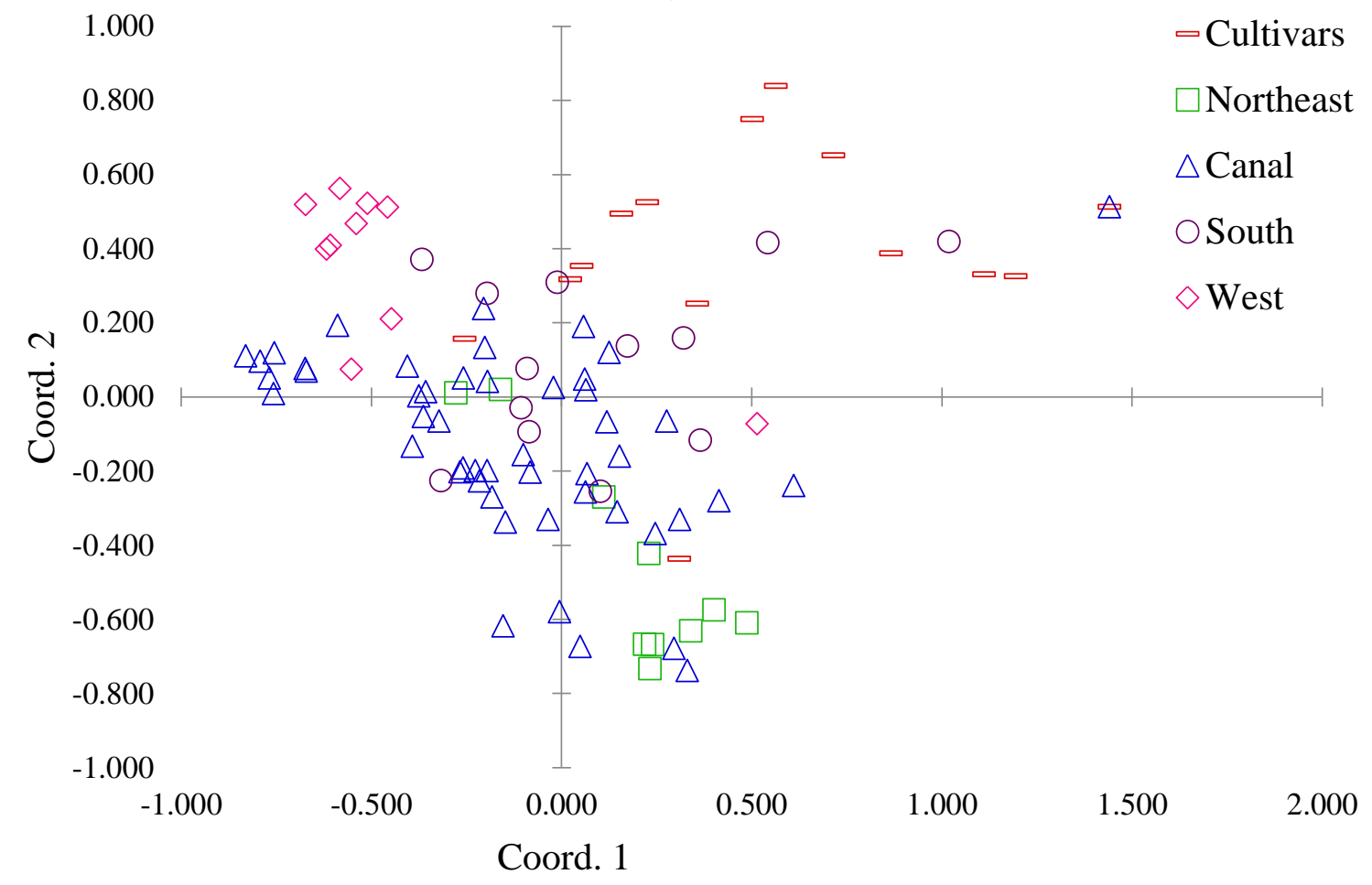


Figure 7

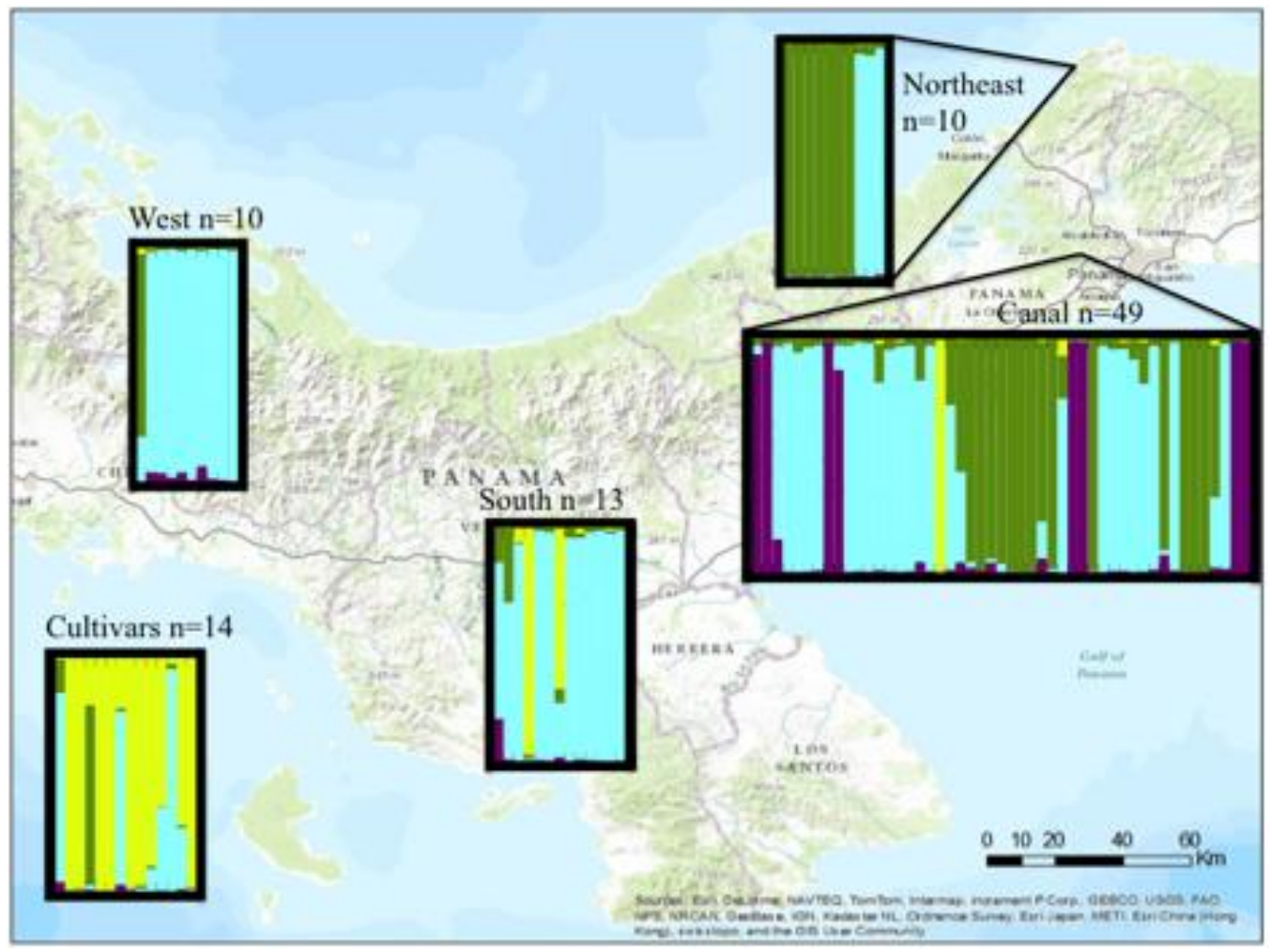

